\title{
Assessing the Service Quality in the Restaurant Industry Using the SERVQUAL Model (A Case of KFC-GHANA, KUMASI)
}

\begin{abstract}
Appiah, Vincentia Serwah
School of Economics and Management, Shijiazhuang Tiedao University

Vincentiaserwaaappiah05@gmail.com

ABSTRACT

Organizations or Industries all over the world strive to provide quality services to their customers or consumers. Aside gaining profit which is the top most priority of service provider organizations, management also try to find ways and means to provide services that satisfy customers. The restaurant industry which provides varieties of services desires to ensure that its customers receive a good quality service. For a better management, sustainability and to gain a lot of customers, it depends or it is based on the quality service the industry is able to provide. The loyalty of customers to stay and patronize the services of KFC-Ghana, Kumasi is determined by the quality service they can provide to customers. The quality-of-service quality of industries is assessed so as to know whether the expectations of customers are being met. Every customer or consumer has an expectation of the services they want to patronize. Customers try to assess the price of product or service itself, the appearance of the industry and even the attitude of staff towards customers. All these mentioned can be based upon to know whether an industry has good quality service or not. The service quality of an industry shows the service quality. The aim of this study was to assess or examine the service quality of the restaurant industry using the SERVQUAL model established by Parasuraman et al (1985). KFC-GHANA, KUMASI was the key focus. The SERVQUAL model which has five (5) dimensions namely; Tangibility, Reliability, Responsiveness, Assurance and Empathy, will be used to measure the service quality of KFC-Ghana, Kumasi, which will also reveal their service quality. The five (5) dimensions have to do with the pricing of products and services of KFC-Ghana, Kumasi, the equipment and appearance of KFC-Ghana, Kumasi as well as the attitudes of the employees of KFC-Ghana, Kumasi. In this study, one hundred and fifty (150) questionnaires were completed by respondents both from the same location as KFC-Ghana, Kumasi and those who are in different locations. Regression analysis was used to assess the impact the independent variables (which are the five dimensions of SERVQUAL model) have on the dependent variable (which is Service quality of KFC-Ghana, Kumasi). Recommendations were made to management of KFC-Ghana, Kumasi and also for further studies.
\end{abstract}

Key words: Service Quality; SERVQUAL Model; Customer Satisfaction

DOI: $10.7176 / \mathrm{JESD} / 12-16-12$

Publication date:August $31^{\text {st }} 2021$

\subsection{Introduction}

The restaurant industry has grown to be one of the most lucrative industries in the world. Customers' demand, for varieties of goods and services are being met by both international and local restaurant chains. The ready-to-eat segment (fast food) has given the industry a new dimension, with fast food restaurants such as Pizza Hut, KFC, and AFC doing brisk business in most parts of the world, as well as in many Ghanaian cities, and successfully expanding their branches. In the past few decades, the restaurant industry has transformed from just a small meal providing facility to a large one that provides different kinds of services and has various functions. These services and functions are highlighted basically to satisfy the needs of its customers. Such level of satisfaction or needs of customers are mainly in connection with the kind of services that are recognized as quality. Hence plenty of probing has been happening for the past few decades to rationalize and prove an instantaneous relationship between the two. During this time, several theories and models are created. Zeithaml, Parasuraman, and Berry (1988) suggested SERVQUAL, an empirically derived tool for service organizations to use to reinforce efficiency. In most service sectors, SERVQUAL scale is mainly used in order to understand the service quality. This approach was built around five main dimensions, each of which has a direct impact on customer satisfaction to varying degrees. There has been a lot of research that has been undertaken in order to understand the effect of SERVQUAL magnitude on customer satisfaction. However, the population sample's differences, cultural beliefs, climate, per capita income, and emotions all play a significant role in assessing it. In his research, he pointed out that, there existed 5 forms of service quality which was supposed to be researched on but noted that, as a result of the limitation of resources in terms of finance and time, the researchers decided to pick and conduct the study on the two most applicable dimensions of SERVQUAL within the local environment. 


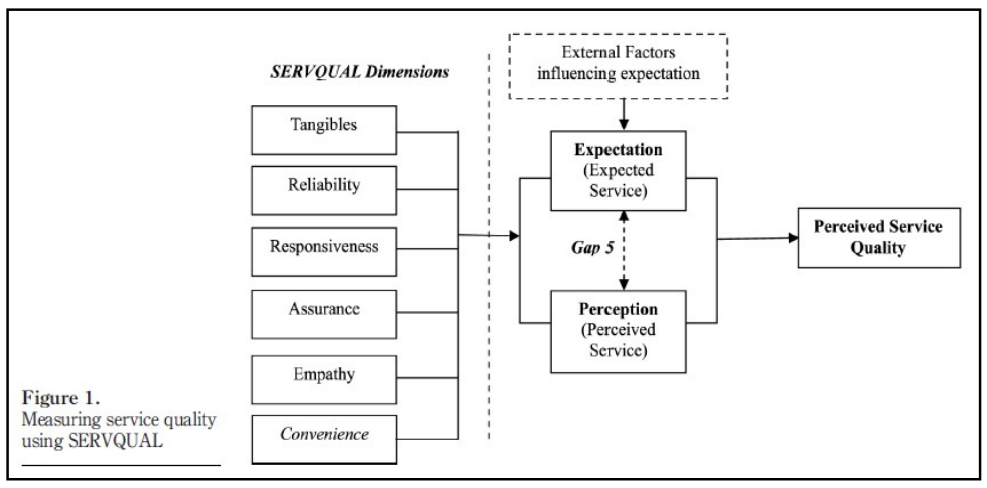

Figure 1-1 SERVQUAL Model

Based on the figure below, Parasuraman et al (1985) in their research realized some attributes that in one way or the other had influence on service quality. The attributes were the important characteristics to improve the customers' expectations and perceptions of services that were delivered. The 10 forms of service quality later reduced to five due to overlap between the ten parameters (Jannadi and Al-Saggaf, 2000). Finally, tangibility, efficiency, responsiveness, assurance, and empathy are the best five dimensions to assess service quality. Parasuraman et al. (1985) also discovered that the range of difference distance between the customer's perceptions before accessing a service in a service centre and what he or she actually perceives after seeing and physically accessing its usage plays a major role in determining their perception of service quality. Service quality based on the above can then be described as the change in customer expectation based on a particular service and how they react after using the said service. If a deficit in service quality arises that the service provider would like to close, a service quality gap exists (Lewis et al., 1994). For instance, a lack of sales, preparation processes, and marketing research; an organization's failure to concentrate on demand quality; an unsystematic service creation service; and a lack of staff training, to name a few examples. This gap model is one of the best-received discoveries, a practice of problem solving and most analytically important contributions to the service literature according to Brown and Bond (1995).

\subsection{Background of Company-KFC-GHANA, KUMASI}

KFC (Kentucky Fried Chicken) is a fast-food chain based in Louisville, Kentucky, that first opened its doors in the 1930s. It is one of the few American brands with a long history of success and innovation. The chain was purchased by PepsiCo, Inc. in 1986, and the name and logo were changed to KFC in 1991. KFC now has over 9,000 locations around the world, including China, Russia, Australia, and Africa. Kentucky Fried Chicken has many goals, most of which include bettering themselves as a company. The company's main goal is to provide good food for customers that puts a smile on their faces, and makes them want to come back for more. Another mission of KFC is to continue to grow the KFC empire and bring a smile to the faces of people all over the world. Another important target for KFC is customer loyalty, and another way they strive to put a smile on their customers' faces. Kentucky Fried Chicken strives to be the best in the business and they do their best to satisfy all customers.

In 2011, KFC opened its first branch in Accra, Ghana's capital. As at now, there are about 19 KFC branches across the country, Ghana. All are franchises owned by an Indian company. There are two branches in Kumasi where this case study is made. Service quality in the service quality of industries has been studied in different directions, from assessing service quality to its impact on other business aspects. Some researchers have identified various possible ways of evaluating service quality and customer satisfaction (Levy, 2009). Other scholars, such as Wilson et al. (2008), in his research proposed that, three things such as the product, price and the price quality, personal and situational variables are determining factor in relation to service quality to the customer. Other researchers such as Wen-Yi, et al also researched on the link between quality management and customer satisfaction. Satisfaction is the major priority of every customer and service providers must always bear it in mind, this is because service providers or producers can never determine whether a customer is satisfied or not unless the service rendered has a positive impact on the consumer. This means that, the quality of a service delivered is a major factor in determining customer satisfaction. (Lee et al., 2000, p. 226). Wilson et al., 2008 , in their studies, other scholars have brought up ideas about customer loyalty and service efficiency. After identifying the key priority of customer value and customer satisfaction, Wang \& Hing-Po (2002, p. 50-60) 
assessed service quality in China's cell phone market and pointed out the major influence existing between service quality, customer satisfaction, value and their various impact on behaviors.

In addition to Lee et al. (2000, p. 226), other researchers conducted investigations on the determinants of service quality and customer loyalty to a particular product in relations to retail department stores and found that, the quality of service rendered has an impact on the behavior and attitude in relation to the department stores. (Sivadas \& Baker-Prewitt, p. 73-82 in Sivadas \& Baker-Prewitt, 2000). This is due to the fact that service quality affects every aspect of a company. Kuo, (2003), performed a research in relation to quality of service relating to the virtual websites among college students from three major Taiwanese universities and found that the forms of service quality have a minimum impact in relation to customer satisfaction. Bennett \& Barkensjo (2005), in their research on service quality with the aim of finding the link that existed between quality and marketing relationships. They tried to connect the results found in their research with other previous research on non-profit organizations, and came up with a result that suggested that "the SERVQUAL approach is also applicable within the non-profit sector" (Bennett \& Barkensjo 2005, p. 102). Negi (2009) investigated the significance of service quality in relation with customer perceptions in determining their general satisfactions in the area of mobile networks, as indicated by Bennett \& Barkensjo (2005). The result was that reliability and network quality were relevant factors to evaluate service quality and he confirms that tangibles, empathy and assurance should not be left out when measuring perceived service quality and satisfaction of customers. Ahmed et al (2010), in their research conducted on service quality came up with a way to determine the link that existed between service quality and customer satisfaction and the reason behind the reselling of the telecom industry among students. They conducted this research with the motivation and idea of making service quality dimensions to research on customer satisfaction through the means of the five (5) SERVQUAL models which included tangibles, responsiveness, empathy, assurance and reliability propounded by Parasuraman et al (1988) to measure service quality. (To confirm the fact that researchers are still working on customer satisfaction especially on its relationship with 4 service quality.)

Among the articles search for past studies on the influence of service quality on organizations, little studies have been conducted to ascertain service quality then relating it with customer satisfaction and other marketing, or business aspects. Little or no researches have been embarked upon in determining the link that existed between satisfaction and service quality by testing the forms of service quality on customer satisfaction. These results agree to the very fact that, customer satisfaction in terms of its relationship with service quality is an important and good area of research in organizations, economics and management. The statistics also shows that; little research has been conducted on the impact satisfaction of the customers in relation with service quality and little studies have been conducted the influence of customer satisfaction on the service quality. Thus, this indicates that there is a need for more research in this area. Researchers conducted in previous studies found out that, service quality and customer satisfaction are certainly related (Baker-Prewitt, 2000; Kuo, 2003; Gera, 2011), in spite of the above researchers, there has been no study conducted to ascertain the service quality dimensions to determine whether it has a close relationship with customer satisfaction. There is a need therefore to evaluate the close relationship existing between service quality and customer satisfaction. Moreover, it has been proven that service quality could be evaluated with the use of the other two dimensions of service quality that is technical and functional (Bennett \& Barkensjo, 2005, p. 102; Laroche et al., 2004) with the customer perspective, yet SERVQUAL model is still a method of evaluation for service quality, there is therefore existing a gap between serve quality and service quality dimensions in different service sectors especially with the SERVQUAL dimensions.

\subsection{Research Questions}

$>$ In this study, few questions have been generated about the service quality dimension (SERVQUAL) on the service quality of KFC KUAMSI, GHANA. The research study is guided by the following research question for the investigations as follows:

$>$ What is the impact of service tangibility on the service quality of KFC-Ghana, Kumasi?

$>$ What is the impact of service reliability on the service quality of KFC-Ghana, Kumasi?

$>$ What is the impact of service responsiveness to the service quality in KFC-Ghana, Kumasi?

$>$ What is the impact of service assurance on the service quality of KFC-Ghana, Kumasi? 
$>$ What is the impact of service empathy on the service quality of KFC-Ghana, Kumasi?

$>$ Which dimensions are the best predictors of overall service quality perceived by the customers in KFCGhana, Kumasi?

\subsection{Research Objectives}

This study has been undertaken to investigate service quality and its impact on the restaurant industry with specific reference to KFC-GHANA, KUMASI. It focused on the SERVQUAL model's five (5) independent variables: tangibles, reliability, responsiveness, assurance, and empathy, as well as the defined dependent variable, customer satisfaction.

The objectives of the study are:

$>$ To determine the impact of service tangibility on the service quality of KFC-Ghana, Kumasi

$>$ To determine the impact service reliability on the service quality of KFC-Ghana, Kumasi

$>$ To determine the impact of service responsiveness to the service quality in KFC-Ghana, Kumasi

$>$ To determine the impact of service quality of service assurance in KFC-Ghana, Kumasi

$>$ To determine the impact of service empathy in KFC-Ghana, Kumasi

$>$ To identify which is the best SERVQUAL dimension perceived by the customer in KFC-Ghana, Kumasi

\subsection{LITERATURE REVIEW}

\subsection{Service Quality}

The literature has recognized the value of service quality in the achievements of most firms by getting to know the impact customer satisfaction has and, and can lead to the loyalty of customers being affected (Al Khattab and Aldehayyat, 2011). The SERVQUAL model's dimensions are one of the most useful metrics of service efficiency. For the first time, "Parasuraman 9 et al. (1985) defined 97 attributes that were condensed into ten (10) dimensions; it was realized that, they had an impact on service quality and were considered as the standards that were essential to access customer expectations and perceptions on delivered service (Kumar et al., 2014);

Consumers look out for the quality of a product or service. (Solomon 2009, p. 413). Quality can also be explained as all the features and characteristics of a product or service which can affect the ability to satisfy a need (Kotler et al., 2002, p. 831). It is self-evident that consistency is linked to the value of a recommendation, which can elicit satisfaction or frustration from the customer. Service quality in the management and marketing literature is said to be the level to which customers' perceptions of service meet or exceed their standards, according to Zeithaml et al (1990), quoted in Bowen \& David.

They said that determining service quality based on the discrepancy between perceived and planned service was an assured way for management to be aware of their shortfalls in how they provide service.

To satisfy customers is the goal of most organizations. Assessing the service quality may be a better thanks to dictate whether the services are good or bad and whether the purchasers will or are satisfied with it. Academics and practitioners have developed and widely used various scales and indexes to measure the service quality, such as the Technical and Functional Quality model (Gronroos, 1984). The SERVQUAL scale which is additionally referred to as the gap model by Parasuraman, et al. (1988) has been proven to be one among the simplest ways to live the standard of services provided to customers. Some scholars have found this form of service assessment to be consistent and accurate (Brown et al., 1993). They said that, when the service perceived by customers is lower than the service that was expected, it then means the service quality was able to meet the needs of customers; and when the service that was perceived happens to be the same as the service that was expected, the apparent conclusion is that service quality is acceptable (Jain et al., 2004, p. 27). According to the way this principle is portrayed, SERVQUAL seems to be the best fit for evaluating service quality from the customer's perspective. This is because when the terms "perceived" and "anticipated" service are used, it is obvious that they refer to the individual who uses or consumes the service; in other words, the consumer or customer. The staff, facilities, 
products. of an organization are given to help solve the problems of customers. In the restaurant industry, one major challenge that has been identified is delivering quality service to customers (UKEssays, 2018). That is being able to provide services that can satisfy or meet the expectations of customers. Providing a quality service is important when it comes to satisfying a customer. The quality of service includes the products and services of the restaurant industry, the people and the surroundings which all come together to strive to meet the needs of customers. The kind of quality service that is provided can influence the industry and the environment. (Munro and Jones 1993) stated that the level of an organization's customers actually depends on the kind of product or service they are able to give as well as the daily contact the customers have with the employees.

\subsection{SERVQUAL Dimensions}

SERVQUAL is a multi-item scale that measures the expectations of customers on service quality. SERVQUAL was introduced by Parasuraman, Zeithaml, and Berry in the 1980s. These dimensions take into consideration the human part of service delivery which are responsiveness, reliability, assurance, empathy, and tangibility. The impact of service quality depends on the service expected and the service perceived. The level of service quality is the difference between expectations and perceptions of service quality of an organization.

1 Tangibility

2 Reliability

3 Responsiveness

4 Assurance

5 Empathy

\subsection{Customer satisfaction}

Those who buy the products or services provided by companies are customers. In other terms, a customer may be a shareholder in a company who pays for an offer made to him by the company in order to meet a need and maximize satisfaction. The terms customer and consumer can be misunderstood at times. An author explained this difference as a customer buys the product and the consumer is the final user of the product (Solomon, 2009.) Customer satisfaction is very important aspect of every company and by so doing, there is a lot of inputs from companies in terms of their customer service delivery and brand maintenance. This is because customer loyalty is a vital tool for every business that deems it fit to succeed in this present age. Products and service quality are key things most companies look out for in their quest to succeed (Awwad, 2012). For the past years, there has been a lot of customer satisfaction indicators which has evolve in recent times and most organizations from various parts of the world use them in managing their affairs. The first indicator which was called the Swedish customer satisfaction barometer (SCSB), was designed by Claes Fornell in the year 1989. He further in 1996 built upon the SCSB in order to develop the American Customer Satisfaction Index (ACSI) which was also used globally. Besides, European Customer Satisfaction Index (ECSI) was also introduced in 11 European countries (Turkyılmaz, 2007). On the basis of this, satisfaction was easily seen based on the fact that, the service quality is also equal to the satisfactions enacted from the product. (Heung, 2000). This means customer satisfaction can only be measured based on the uniqueness of how a service is delivered and how this same service is able to satisfy the need of customers.

A customer that is pleased with a product or service rendered where his or her expectations are met is known as satisfaction. Satisfaction can also be a person's feelings of desire or dissatisfaction that comes as a result of likening a service or a product's supposed service quality. (Kotler \& Keller, 2009). As a matter of fact, satisfaction can be explained as when a customer is pleased with the products or services delivered by an organization or an individual; or it can be the state of being happy with a situation. Satisfaction varies from one person to a different because it's utility. Customer happiness, which is a symbol of customer loyalty, is and has always been the most important aspect of any company. Customer satisfaction is explained by Tse \& Wilton $(1988$, p. 204) as the reaction a customer shows after measuring the expected service and the perceived service. The consumer's reaction to the assessment of the perceived difference, thus considering satisfaction as an overall post-purchase evaluation by the consumer" (Fornell, 1992, p. 11). Some authors claimed that there is no specific definition of customer satisfaction, but after reviewing other definitions, they gathered that customer satisfaction can be said to be the reaction that comes before and after an experience of patronizing a product or service at a specific time (i.e., post-purchase, post-consumer), (Giese \& Cote, p. 15 in Giesse \& Cote, 2000). Another author agrees with this concept that the level of a customer's satisfaction is based on the reaction he or she shows after interacting with a supplier or seller (Sureshchander et al., 2002, p. 364). It is factual that, there's no specific definition of customer satisfaction since because the years passes, different authors come up with different definitions. (Kotler et al., 2002, p. 8) also explained that customer satisfaction is the level of how a service is able to meet a customer's needs. Schiffman \& Karun (2004) also defined customer satisfaction as how a person 
measures a product or service according to his or her expectations. In a nutshell, consumer satisfaction can be said to be described as the pleasure one gets from a consumed product or a delivered service.

Measuring consumer loyalty can be daunting at times because it requires a conscious commitment to live human emotions. As a result, several previous researchers proposed that "the best way to consider how consumers feel, and what they need is to question them," which referred to informal interventions (Levy, 2009, p. 6; NBRI, 2009). In his research, Levy (2009, p. 6) proposed three methods for assessing customer satisfaction:

A survey in which consumer input is often converted into quantitative data: Customers' opinions are revealed by focus groups or casual conversations moderated by a professional moderator. Reading blocks and chatting to consumers are examples of informal interventions. Asking each client is beneficial so that the organization will know everyone's thoughts, but it is inconvenient that the company will have to gather this knowledge from each customer (NBRI, 2009). The National Business Research Institute (NBRI) proposed several dimensions for assessing consumer loyalty, including:

- Service quality

- Beyond a doubt

- Delivery speed $\bullet$ Pricing $・$ Complaints or issues

- Your employees' trustworthiness

- The closeness of your relationship with your firm's contacts

- Other forms of services needed

- Your place in the minds of your clients

\subsection{Conceptual Framework of the studies}

Conceptual framework is made up of ideas, descriptions, variables and other known theories existing and which are recognized by individuals who carry out research works and the actual reason is to know how the research work is essential to the researcher. In choosing variables in any given research, the researcher must ensure that the variables which is the most important aspect of the research can be measured. This characteristic most especially is very important when carry out a research that involves variables. This means that, the variables in the research can be measured when one is drafting his or her questionnaire. (Norzaidi 2013). The framework must point out an overall thoughtfulness and meaning which are important to the research that is been carried out.The conceptual framework in every research involves active research and reading for the researcher to arrive at it. It is therefore not easily available for the researcher to use at his or her discretion. In order to find related hypotheses and analytic models that are important to the SERVQUAL model, the researcher must study course readings as well as relevant literature such as journals and papers. The appropriateness, easier usage, and being able to explain properly are all taken into consideration when choosing a theory (Trochim, 2006).

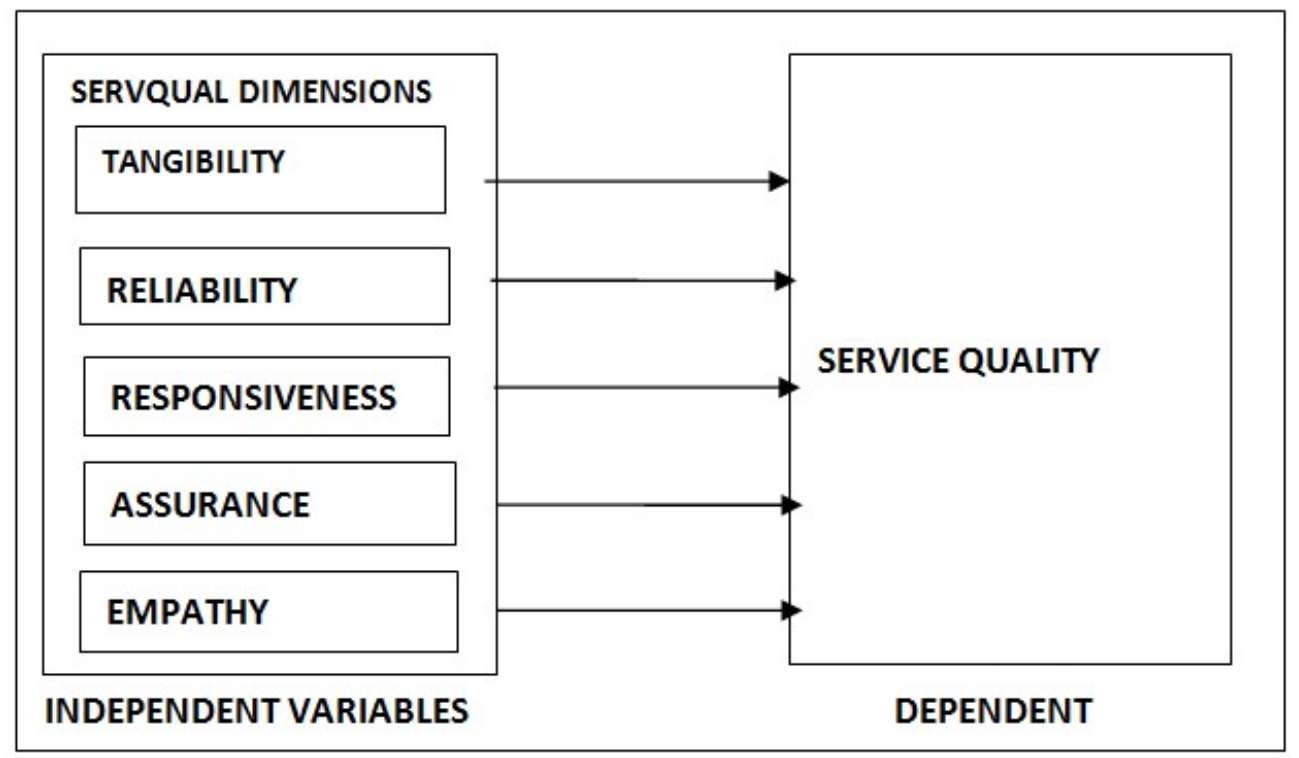

Figure 2-1 Independent variables and dependent variable 
The framework above shows a proposed framework to serve as foundation of this study. It is modified from the Zeithaml et al (1985) gap model theory. Purpose of this study is to examine how Tangibility, Reliability, Responsiveness, Assurance and Empathy of service which are the independent variables can have an impact on the dependent variable, Service Quality of KFC-Ghana, Kumasi.

The Hypothesis of the study

H1: Service Tangibility of Consumers' Expectations has a positive significant impact on the Service Quality of KFC- GHANA, KUMASI.

H2: Service Tangibility of Consumers' Perceptions has a positive significant impact on the Service Quality of KFC-GHANA, KUMASI.

H3: Service Reliability of Consumers' Expectations has a positive significant impact on the Service Quality of KFC-GHANA, KUMASI.

H4: Service Reliability of Consumers' Perceptions has a positive significant impact on the Service Quality of KFC-GHANA, KUMASI.

H5: Service Responsiveness of Consumers' Expectations has a positive significant impact on the Service Quality of KFC-GHANA, KUMASI.

H6: Service Responsiveness of Consumers' Perceptions has a positive significant impact on the Service Quality of KFC-GHANA, KUMASI.

H7: Service Assurance of Consumers' Expectations has a positive significant impact on the Service Quality of KFC-GHANA, KUMASI.

H8: Service Assurance of Consumers' Perceptions has a positive significant impact on the Service Quality of KFC-GHANA, KUMASI.

H9: Service Empathy of Consumers' Expectations has a positive significant impact on the Service Quality of KFC-GHANA, KUMASI.

H10: Service Empathy of Consumers' Perceptions has a positive significant impact on the Service Quality KFCGHANA, KUMASI.

\subsection{RESEARCH METHODOLOGY}

3.1 Quantitative and Qualitative Research

Quantitative research can be explained as the steps involved in the gathering and analyzing of numerical data that is usually gotten from questionnaires, surveys, checklists, and tests. It throws more light on statistical, mathematical, and the numerical analysis of data using the techniques of a computer. Qualitative research is objective-based research that provides participants with measurable statistics that help to quantify their views and behaviors. One significant feature of quantitative research is that it assumes the environment in which the research is carried out is stable and uniform and so it defines the problems and questions of the findings and generates hypothesis that foretell the results of the research before the start of findings. However, there is often no or limited reason for the explanation of the reason why respondents chose particular answers. In this study, data are analyzed and presented in statistical tools of percentages and others, which the researcher hopes will not yield any unbiased result in the generalization of a population. Qualitative research, can also be defined as a study procedure that presents respondents with meaningful concepts and characters mostly in metaphors, symbols, and the vivid explanation of things in line with the social constructivist paradigm to make a real constructed nature. This procedure seeks to cover a deeper meaning and rich understanding which makes researchers interest in human behavior and experiences like beliefs and emotions. The approach does not involve pre-determined hypotheses but they clearly could identify problems and topics that they want to explore and maybe guided by theoretical evidence to prove their findings and investigations.

\subsection{Research Design}

The research design is the overall approach you choose to combine the various components of the analysis in a continuous and rational manner, making sure that all the issues associated with this research are carefully addressed. Therefore, this research applied the descriptive research design to help in assessing the service quality of the restaurant industry using the SERVQUAL model in KFC-Ghana, Kumasi. According to Mugenda (2013), a descriptive study design is a rigorous observational investigation under which the researcher has little clear control on the independent variable since it has already manifested and therefore cannot be influenced inherently. Descriptive analysis, according to Miller (2013), portrays an accurate profile of individuals, behaviors, and contexts, giving the researcher a comprehension of the interest of a person or a group who have expectations, perceptions, and concerns. One of the most significant advantages of descriptive analysis is that it is performed in a completely normal and unaltered setting, resulting in a true representation of an experiment with results. It is often used as a reference to more quantitative testing designs, and it gives a general description of which variables should be measured in order to produce rich data that contributes to valuable recommendations. The 
findings of this study design cannot be repeated because it often employs observational methods. Furthermore, the findings of descriptive study cannot be used to arrive at a definitive answer or to confirm or disprove a hypothesis.

\subsection{Population}

Fraeckel \& Warren (2015), in their studies, explained as a total set of persons (subjects or events) who have some features in common and are in the interest of the researcher and the research work as a whole. All persons living far and near KFC-Ghana, Kumasi formed the population of this study, however, close attention was given to persons who patronizes the KFC.

\subsection{Data Analysis}

Data analysis is the method of making explanations and conclusions on the findings of the study (Creswell, 2003). The study applied both quantitative and qualitative procedures to analyze the primary data received from the questionnaire that were given out to the customers of KFC-Ghana, Kumasi. The technique used in this study was a descriptive statistical technique of data analysis with the aid of the statistical software called Statistical Product for Service Solution (SPSS, version 26), the Google Form platform for the online questionnaire and Microsoft Excel software. Firstly, as and when each respondent responds to the questionnaire through the shared link, the Google form software sorts out the responds into common codes and interpret the results in statistical tools which includes graphs, pie-charts, frequency tables. The data was then transferred onto the SPSS software where the hypothesis of the study was tested through factor analysis, specifically, regression tools. Since the research is mainly descriptive purposes, the results were finally presented in logical inferences and interpretations in percentages and frequencies.

\subsection{DATA ANALYSIS AND OBSERVATION}

\subsection{Age Distribution of Respondents}

The distribution of respondents by age were categorized into the following; 15-19, 20-24, 25-29, 30-34, 35-39, 40-44, and 45-50.the reason for distributing respondents by their age is for the researcher and other stakeholders namely, management and staff of KFC-GHANA, Kumasi to be able to identify the age group that dominates as respondents to the study as well as consumers for KFC-GHANA, Kumasi.

Table 4-1 and figure 4-1 show that out of the total number of respondents (150), forty-three (43) respondents representing $28.7 \%$ were under the age of $40-44$, thirty (30) respondents representing $20 \%$ were under the age of 35-39. Moreover, 7 respondents representing 4.7\% were under the age of 25-29 and only two (2) of the total respondents resenting $1.3 \%$ were under the ages of 45-50. The results presented in table 4-1 and figure 4-1 could be interpreted that majority of the respondents of the study who double up as consumers of KFC-GHANA, Kumasi are between the ages of 40-44. This result could further be interpreted that more adults between the ages of 40-44 are mostly the people who patronize the services and products of KFC-GHANA, KUMASI. Also, only 2 respondents representing a simple minority of $1.3 \%$ were the least of age category of respondents and consumers to both the study and KFC-GHANA, Kumasi.

\begin{tabular}{lcc} 
& \multicolumn{2}{c}{ Table $4-1$ Age Distribution of Respondents } \\
\hline Age & Number of Responses & Percentage \\
\hline $15-19$ & 21 & 14.0 \\
$20-24$ & 23 & 15.3 \\
$25-29$ & 7 & 4.7 \\
$30-34$ & 24 & 16.0 \\
$35-39$ & 30 & 20.0 \\
$40-44$ & 43 & 28.7 \\
$45-50$ & 2 & 1.3 \\
\hline Total & $\mathbf{1 5 0}$ & $\mathbf{1 0 0}$ \\
\hline
\end{tabular}

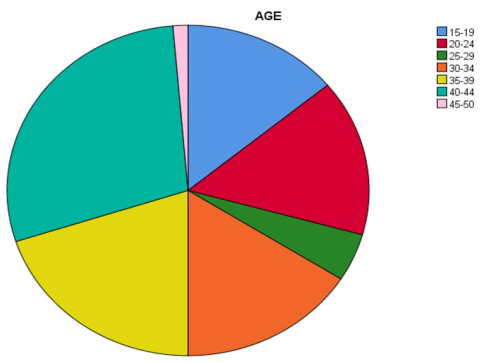

Figure 4-1 Age Distribution of Respondents 


\subsubsection{Distribution of Respondents by Gender}

The gender distribution of respondents was male and female. This enabled the researcher to identify the number of respondents that forms the majority of these two groups. Results from table 4-2 and figure 4-2 indicate that 90 respondents representing $60 \%$ were females. Also 60 respondents representing $40 \%$ were males. This could be said that majority of the respondents who made themselves available to this study were females. This could further be interpreted that majority of the gender that visits KFC-GHANA, Kumasi are females.

Table 4-2 Distribution of Respondents by Gender

\begin{tabular}{lcc}
\hline Gender & Number of Responses & Percentage \\
\hline Male & 60 & 40.0 \\
Female & 90 & 60.0 \\
\hline Total & $\mathbf{1 5 0}$ & $\mathbf{1 0 0}$ \\
\hline
\end{tabular}

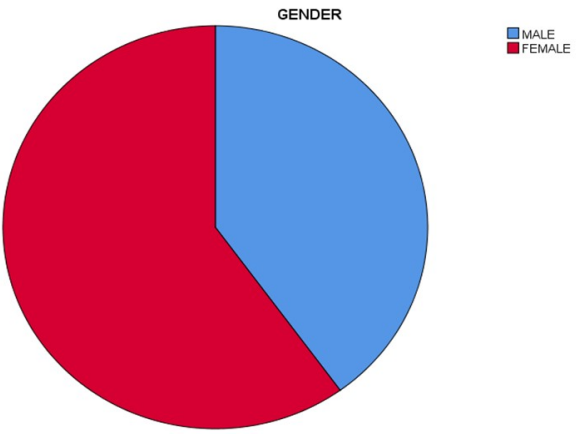

Figure 4-2 Distribution of Respondents by Gender

\subsubsection{Distribution of Respondents by Location}

The respondents were grouped under two different locations; Those who live around the same area as KFCGHANA, Kumasi (Same) and those that live at different locations (Different). This will help to identify which group among these form majority of consumers of KFC-GHANA, Kumasi.

The table 4-3 and figure 4-3 show that 86 of the respondents representing $57.3 \%$ were those residing at the same location as KFC-GHANA, Kumasi. The results also identified that 64 respondents representing $42.7 \%$ were those residing at different locations other than KFC-GHANA, Kumasi.

The results could be statistically interpreted as majority of the respondents to this study live around the same premise of KFC-GHANA, Kumasi. Also, minority of the respondents representing $42.7 \%$ reside at different locations.

Table 4-3 Distribution of Respondents by Location

\begin{tabular}{lcc}
\hline Location & Number of Responses & Percentage \\
\hline Same & 86 & 57.3 \\
Different & 64 & 42.7 \\
\hline Total & $\mathbf{1 5 0}$ & $\mathbf{1 0 0}$ \\
\hline
\end{tabular}

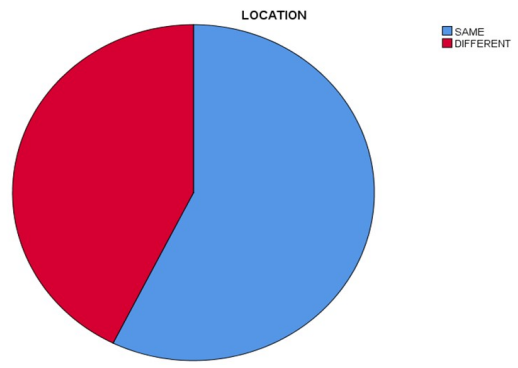

Figure 4-3 Distribution of Respondents by Location 
4.1.4 Distribution of Consumers by their Usage of the Services of KFC-GHANA, Kumasi.

Under this section, the researcher grouped consumer's usage of services at KFC-GHANA, Kumasi with the following durations; Hourly, Weekly, Monthly, and Other. The results from table $4-4$ shows that out of the total of 150 respondents, 74 representing $49.3 \%$ use the services of KFC-GHANA, Kumasi every month. Also, only 3 of the respondents representing $2.0 \%$ use the services of KFC-GHANA, Kumasi every Hour. This could be interpreted that majority of the respondents to the study patronize the services of KFC-GHANA, Kumasi monthly.

Table 4-4 Distribution of Consumers by their Usage of the Services of KFC-GHANA, Kumasi

\begin{tabular}{lcc}
\hline Duration & Frequency & Percentage \\
\hline Hourly & 3 & 2.0 \\
Weekly & 59 & 39.3 \\
Monthly & 74 & 49.3 \\
Other & 14 & 9.3 \\
\hline Total & $\mathbf{1 5 0}$ & $\mathbf{1 0 0}$
\end{tabular}

4.2 Data Tests

This segment presents an analysis of data gathered from participants' answers to Section B (Consumers' Expectations) and section C (Consumers' Perceptions) in the questionnaire where participants were asked to rate the importance of statements and their applicability.

4.2.1 The Impact of Service Tangibility of Consumers' Expectations and Perceptions on the Service Quality of KFC-Ghana, Kumasi

The researcher aimed to determine the impact of service Tangibility of consumers' Expectations and Perceptions on the Service Quality of KFC-Ghana, Kumasi. Using the five (5) point likert scale of 1= Totally Agree, 2= Agree, $3=$ Neutral, $4=$ Disagree, $5=$ Totally Disagree. The researcher utilized descriptive statistics and one sample t-test to analyze and interpret every data gathered. The significance level is placed at $5 \%$. The expected mean in this study is " 5 " as it indicates its importance.

Table 4-5 Descriptive Statistics for Service Tangibility of Consumers' Expectations and Perception

\begin{tabular}{|c|c|c|c|c|c|c|c|c|}
\hline & $\mathrm{N}$ & Minimum & Maximum & Sign. & Mean & $\begin{array}{l}\text { Std. } \\
\text { Deviation }\end{array}$ & Variance & Skewness \\
\hline $\begin{array}{l}\text { Physical } \\
\text { facilities } \\
\text { should be } \\
\text { visually } \\
\text { appealing }\end{array}$ & $\begin{array}{l}15 \\
0\end{array}$ & 1.0 & 4.0 & .0124 & 1.287 & 0.6058 & 0.367 & 2.339 \\
\hline $\begin{array}{l}\text { KFC should } \\
\text { have modern } \\
\text { equipment }\end{array}$ & $\begin{array}{l}15 \\
0\end{array}$ & 1.0 & 4.0 & .0223 & 1.587 & 0.5929 & 0.351 & 0.638 \\
\hline $\begin{array}{l}\text { Employees } \\
\text { should be well } \\
\text { dressed }\end{array}$ & $\begin{array}{l}15 \\
0\end{array}$ & 1.0 & 3.0 & .0110 & 1.373 & 0.5501 & 0.303 & 1.131 \\
\hline $\begin{array}{l}\text { Neat and Nice } \\
\text { premises }\end{array}$ & $\begin{array}{l}15 \\
0\end{array}$ & 1.0 & 5.0 & .0021 & 1.633 & 0.6797 & 0.462 & 1.779 \\
\hline $\begin{array}{l}\text { Up to date } \\
\text { equipment at } \\
\text { Centers }\end{array}$ & $\begin{array}{l}15 \\
0\end{array}$ & 1.0 & 3.0 & .0121 & 1.253 & 0.5333 & 0.284 & 2.034 \\
\hline $\begin{array}{l}\text { Physical } \\
\text { facilities are } \\
\text { visually } \\
\text { appealing }\end{array}$ & $\begin{array}{l}15 \\
0\end{array}$ & 1.0 & 4.0 & .0213 & 1.767 & 0.5235 & 0.274 & 0.071 \\
\hline $\begin{array}{l}\text { Employees are } \\
\text { well dressed }\end{array}$ & $\begin{array}{l}15 \\
0\end{array}$ & 1.0 & 3.0 & .0324 & 1.227 & 0.4797 & 0.230 & 2.029 \\
\hline $\begin{array}{l}\text { Neat and Nice } \\
\text { environment }\end{array}$ & $\begin{array}{l}15 \\
0\end{array}$ & 1.0 & 3.0 & .0123 & 1.340 & 0.5159 & 0.266 & 1.122 \\
\hline
\end{tabular}

4.2.2 The Impact of Service Reliability of Consumers' Expectations and Perceptions on the Service Quality of KFC-Ghana, Kumasi

The researcher aimed to determine the impact of service Reliability of consumers' Expectations and Perceptions on the Service Quality of KFC-Ghana, Kumasi. Using the five (5) point likert scale of 1= Totally Agree, 2= 
Agree, $3=$ Neutral, $4=$ Disagree, $5=$ Totally Disagree. The researcher utilized descriptive statistics and one sample t-test to analyze and interpret every data gathered. The significance level is placed at $5 \%$.

Table 4-6 Descriptive Statistics for Service Reliability of Consumers' Expectations and Perceptions

\begin{tabular}{|c|c|c|c|c|c|c|c|c|}
\hline & $\mathrm{N}$ & Minimum & Maximum & Sign. & Mean & $\begin{array}{l}\text { Std. } \\
\text { Deviation }\end{array}$ & Variance & Skewness \\
\hline $\begin{array}{l}\text { Provider } \\
\text { Promises } \\
\text { should be } \\
\text { Fulfilled on } \\
\text { Time }\end{array}$ & 150 & 1.0 & 3.0 & .0202 & 1.347 & 0.504 & 0.255 & 0.965 \\
\hline $\begin{array}{l}\text { Customer } \\
\text { problems } \\
\text { should be } \\
\text { treated with } \\
\text { Sincere } \\
\text { interest }\end{array}$ & 150 & 1.0 & 3.0 & .0222 & 1.480 & 0.5522 & 0.305 & 0.565 \\
\hline $\begin{array}{l}\text { Perform } \\
\text { service right } \\
\text { the first time }\end{array}$ & 150 & 1.0 & 4.0 & .0199 & 1.327 & 0.5734 & 0.329 & 1.795 \\
\hline $\begin{array}{l}\text { Provide } \\
\text { service at } \\
\text { promised } \\
\text { time and } \\
\text { keep records } \\
\text { accurate }\end{array}$ & 150 & 1.0 & 4.0 & .0216 & 1.440 & 0.5732 & 0.329 & 1.105 \\
\hline $\begin{array}{l}\text { Able to } \\
\text { provide } \\
\text { solutions as } \\
\text { promised }\end{array}$ & 150 & 1.0 & 4.0 & .0185 & 1.233 & 0.5362 & 0.287 & 2.520 \\
\hline $\begin{array}{l}\text { Customer } \\
\text { problems } \\
\text { should be } \\
\text { sincerely } \\
\text { treated }\end{array}$ & 150 & 1.0 & 3.0 & .0247 & 1.647 & 0.5692 & 0.324 & 0.177 \\
\hline $\begin{array}{l}\text { Provider } \\
\text { performs } \\
\text { service right } \\
\text { the first time }\end{array}$ & 150 & 1.0 & 3.0 & .0195 & 1.300 & 0.5149 & 0.265 & 1.465 \\
\hline $\begin{array}{l}\text { Provide the } \\
\text { service at } \\
\text { promised } \\
\text { time }\end{array}$ & 150 & 1.0 & 4.0 & .0205 & 1.367 & 0.6066 & 0.368 & 1.624 \\
\hline
\end{tabular}

4.2.3 The Impact of Service Responsiveness of Consumers' Expectations and Perceptions on the Service Quality of KFC-Ghana, Kumasi

The researcher aimed to determine the impact of service Responsiveness of consumers' Expectations and Perceptions on the Service Quality of KFC-Ghana, Kumasi. Using the five (5) point likert scale of $1=$ Totally Agree, $2=$ Agree, $3=$ Neutral, $4=$ Disagree, $5=$ Totally Disagree. The researcher utilized descriptive statistics and one sample t-test to analyze and interpret every data gathered. The significance level is placed at $5 \%$. 
Journal of Economics and Sustainable Development ISSN 2222-1700 (Paper) ISSN 2222-2855 (Online)

Table 4-7 Descriptive Statistics for Service Responsiveness of Consumers' Expectations and

Perceptions.

\begin{tabular}{|c|c|c|c|c|c|c|c|c|}
\hline & $\mathrm{N}$ & Minimum & Maximum & Sign. & Mean & $\begin{array}{l}\text { Std. } \\
\text { Deviation }\end{array}$ & Variance & Skewness \\
\hline $\begin{array}{l}\text { Information } \\
\text { should be } \\
\text { attainable }\end{array}$ & 150 & 1.0 & 3.0 & .0158 & 1.233 & 0.4549 & 0.207 & 1.699 \\
\hline $\begin{array}{l}\text { Give } \\
\text { prompt } \\
\text { services to } \\
\text { customers }\end{array}$ & 150 & 1.0 & 3.0 & .0237 & 1.580 & 0.5467 & 0.299 & 0.176 \\
\hline $\begin{array}{l}\text { Never be } \\
\text { busy to } \\
\text { serve } \\
\text { customers }\end{array}$ & 150 & 1.0 & 2.0 & .0179 & 1.193 & 0.3962 & 0.157 & 1.569 \\
\hline $\begin{array}{l}\text { Willing to } \\
\text { serve } \\
\text { customers }\end{array}$ & 150 & 1.0 & 3.0 & .0198 & 1.320 & 0.4822 & 0.232 & 0.961 \\
\hline $\begin{array}{l}\text { Information } \\
\text { should } \\
\text { reach out to } \\
\text { customers }\end{array}$ & 150 & 1.0 & 3.0 & .0168 & 1.120 & 0.3829 & 0.147 & 3.379 \\
\hline $\begin{array}{l}\text { Prompt } \\
\text { services to } \\
\text { customers }\end{array}$ & 150 & 1.0 & 3.0 & .0234 & 1.560 & 0.5614 & 0.315 & 0.337 \\
\hline $\begin{array}{l}\text { Always } \\
\text { ready to } \\
\text { help } \\
\text { customers }\end{array}$ & 150 & 1.0 & 3.0 & .0198 & 1.320 & 0.5350 & 0.286 & 1.429 \\
\hline $\begin{array}{l}\text { Never be } \\
\text { busy to help } \\
\text { customers }\end{array}$ & 150 & 1.0 & 4.0 & .0199 & 1.327 & 0.6185 & 0.383 & 2.240 \\
\hline
\end{tabular}

4.2.4 The Impact of Service Assurance of Consumers' Expectations and Perceptions on the Service Quality of KFC-Ghana, Kumasi

The researcher aimed to determine the impact of service Assurance of consumers' Expectations and Perceptions on the Service Quality of KFC-Ghana, Kumasi. Using the five (5) point likert scale of 1= Totally Agree, 2= Agree, $3=$ Neutral, $4=$ Disagree, $5=$ Totally Disagree. The researcher utilized descriptive statistics and one sample t-test to analyze and interpret every data gathered. The significance level is placed at $5 \%$. 
Journal of Economics and Sustainable Development

\begin{tabular}{|c|c|c|c|c|c|c|c|c|}
\hline & $\mathrm{N}$ & Minimum & Maximum & Sign. & Mean & $\begin{array}{l}\text { Std. } \\
\text { Deviation }\end{array}$ & Variance & Skewness \\
\hline $\begin{array}{l}\text { Behavior of } \\
\text { Employees } \\
\text { should } \\
\text { install } \\
\text { confidence } \\
\text { in } \\
\text { customers }\end{array}$ & 150 & 1.0 & 4.0 & .0213 & 1.420 & 0.5938 & 0.353 & 1.289 \\
\hline $\begin{array}{l}\text { Customers } \\
\text { should feel } \\
\text { safe in } \\
\text { transacting } \\
\text { with } \\
\text { Employees }\end{array}$ & 150 & 1.0 & 4.0 & .0227 & 1.513 & 0.6102 & 0.372 & 1.116 \\
\hline $\begin{array}{l}\text { Employees } \\
\text { should be } \\
\text { polite }\end{array}$ & & 1.0 & 3.0 & .0193 & 1.287 & 0.5352 & 0.286 & 1.720 \\
\hline $\begin{array}{l}\text { Employees } \\
\text { should } \\
\text { have } \\
\text { knowledge } \\
\text { to respond } \\
\text { to } \\
\text { customers }\end{array}$ & 150 & 1.0 & 3.0 & .0205 & 1.367 & 0.5235 & 0.274 & 0.981 \\
\hline $\begin{array}{l}\text { Employees } \\
\text { behavior } \\
\text { should } \\
\text { install } \\
\text { confidence } \\
\text { in } \\
\text { customers }\end{array}$ & 150 & 1.0 & 4.0 & .0177 & 1.180 & 0.4925 & 0.243 & 3.110 \\
\hline $\begin{array}{l}\text { Customers } \\
\text { should be } \\
\text { safe to } \\
\text { transact } \\
\text { with } \\
\text { employees }\end{array}$ & 150 & 1.0 & 3.0 & .0213 & 1.420 & 0.5824 & 0.339 & 1.040 \\
\hline $\begin{array}{l}\text { Employees } \\
\text { should be } \\
\text { polite }\end{array}$ & 150 & 1.0 & 3.0 & .0188 & 1.253 & 0.4803 & 0.231 & 1.684 \\
\hline $\begin{array}{l}\text { Employees } \\
\text { should be } \\
\text { able to } \\
\text { respond to } \\
\text { customers }\end{array}$ & 150 & 1.0 & 3.0 & .0207 & 1.380 & 0.5637 & 0.318 & 1.170 \\
\hline
\end{tabular}

4.2.5 The Impact of Service Empathy of Consumers' Expectations and Perceptions on the Service Quality of KFC-Ghana, Kumasi

The researcher aimed to determine the impact of service Empathy of consumers' Expectations and Perceptions on the Service Quality of KFC-Ghana, Kumasi. Using the five (5) point likert scale of $1=$ Totally Agree, $2=$ Agree, $3=$ Neutral, $4=$ Disagree, $5=$ Totally Disagree. The researcher utilized descriptive statistics and one sample t-test to analyze and interpret every data gathered. The significance level is placed at $5 \%$. 
Journal of Economics and Sustainable Development ISSN 2222-1700 (Paper) ISSN 2222-2855 (Online)

\begin{tabular}{|c|c|c|c|c|c|c|c|c|}
\hline & $\mathbf{N}$ & Minimum & Maximum & Sign. & Mean & $\begin{array}{l}\text { Std. } \\
\text { Deviation }\end{array}$ & Variance & Skewness \\
\hline $\begin{array}{l}\text { Staff must } \\
\text { give } \\
\text { customer } \\
\text { attention }\end{array}$ & 150 & 1.0 & 4.0 & .0175 & 1.167 & 0.4399 & 0.194 & 3.187 \\
\hline $\begin{array}{l}\text { Operating } \\
\text { hours be } \\
\text { convenient } \\
\text { to all } \\
\text { customers }\end{array}$ & 150 & 1.0 & 3.0 & .0238 & 1.587 & 0.5075 & 0.258 & -0.199 \\
\hline $\begin{array}{l}\text { Personal } \\
\text { service } \\
\text { should be } \\
\text { available } \\
\text { to all }\end{array}$ & 150 & 1.0 & 3.0 & .0210 & 1.400 & 0.5556 & 0.309 & 0.999 \\
\hline $\begin{array}{l}\text { Employees } \\
\text { must } \\
\text { understand } \\
\text { specific } \\
\text { needs of } \\
\text { customers }\end{array}$ & 150 & 1.0 & 4.0 & .0237 & 1.580 & 0.6050 & 0.366 & 0.886 \\
\hline $\begin{array}{l}\text { Employees } \\
\text { give } \\
\text { customer } \\
\text { individual } \\
\text { attention }\end{array}$ & 150 & 1.0 & 4.0 & .0173 & 1.153 & 0.4596 & 0.211 & 3.502 \\
\hline $\begin{array}{l}\text { Operating } \\
\text { hours are } \\
\text { convenient } \\
\text { to all }\end{array}$ & 150 & 1.0 & 4.0 & .0252 & 1.680 & 0.6379 & 0.407 & 1.025 \\
\hline $\begin{array}{l}\text { Employees } \\
\text { give } \\
\text { customers } \\
\text { personal } \\
\text { service }\end{array}$ & 150 & 1.0 & 4.0 & .0182 & 1.213 & 0.5627 & 0.317 & 2.763 \\
\hline $\begin{array}{l}\text { Employees } \\
\text { must } \\
\text { understand } \\
\text { unique } \\
\text { needs of } \\
\text { customers }\end{array}$ & 150 & 1.0 & 3.0 & .0174 & 1.160 & 0.4027 & 0.162 & 2.478 \\
\hline
\end{tabular}

\subsection{REGRESSION ANALYSIS (TESTING OF HYPOTHESIS)}

This section of the study presents the outcome of the hypothesis that were formulated in the previous chapter (Chapter One) by the researcher. The hypothesis are as follows:

H1: Service Tangibility of Consumers' Expectations has a positive significant impact on the Service Quality of KFC- GHANA, KUMASI.

H2: Service Tangibility of Consumers' Perceptions has a positive significant impact on the Service Quality of KFC-GHANA, KUMASI.

H3: Service Reliability of Consumers' Expectations has a positive significant impact on the Service Quality of KFC-GHANA, KUMASI.

H4: Service Reliability of Consumers' Perceptions has a positive significant impact on the Service Quality of KFC-GHANA, KUMASI.

H5: Service Responsiveness of Consumers' Expectations has a positive significant impact on the Service Quality of KFC-GHANA, KUMASI.

H6: Service Responsiveness of Consumers' Perceptions has a positive significant impact on the Service Quality of KFC-GHANA, KUMASI.

H7: Service Assurance of Consumers' Expectations has a positive significant impact on the Service Quality of KFC-GHANA, KUMASI.

H8: Service Assurance of Consumers' Perceptions has a positive significant impact on the Service Quality of KFC-GHANA, KUMASI. 
H9: Service Empathy of Consumers' Expectations has a positive significant impact on the Service Quality of KFC-GHANA, KUMASI.

H10: Service Empathy of Consumers' Perceptions has a positive significant impact on the Service Quality KFCGHANA, KUMASI.

4.3.1 Impact of Service Tangibility of Consumers' Expectations on service quality of KFC-GHANA, KUMASI(H1)

The first hypothesis (H1), Service Tangibility of Consumers' Expectations has a positive significant impact on the Service quality of KFC- GHANA, KUMASI is presented in the table below:

Considering the data presented in the table below, two out of the three items identified under the independent variable (Service Tangibility of Consumers' Expectations) established a statistically significant $(0.002 ; 0.00<$ 0.05 ) relationship with the dependant variable (Service quality of KFC- GHANA, KUMASI). A further with the help of stepwise regression analysis revealed an adjusted R square figure of 0.392 .

\begin{tabular}{|c|c|c|c|c|c|}
\hline & B & $\begin{array}{l}\text { Std. } \\
\text { Error }\end{array}$ & Std. Beta & $\mathrm{T}$ & Sig. \\
\hline $\begin{array}{l}\text { (Constant) } \\
\text { KFC should } \\
\text { h hah }\end{array}$ & $\begin{array}{r}-0.074 \\
0.230\end{array}$ & $\begin{array}{l}0.145 \\
0.074\end{array}$ & 0.225 & $\begin{array}{c}-0.512 \\
3.110\end{array}$ & $\begin{array}{l}0.610 \\
0.0022\end{array}$ \\
\hline $\begin{array}{l}\text { Employees } \\
\text { should }\end{array}$ & 0.511 & 0.071 & 0.464 & 7.155 & 0.000 \\
\hline $\begin{array}{l}\text { Neat a good } \\
\text { product } \\
\text { Dependent Var }\end{array}$ & $\begin{array}{r}0.180 \\
\text { ERVICE }\end{array}$ & $\frac{0.065}{\text { YOF KF }}$ & $\frac{0.202}{1, \text { KUMASI }}$ & 2.762 & 0.006 \\
\hline Model & R & $\begin{array}{l}\mathrm{R} \\
\text { square }\end{array}$ & $\begin{array}{l}\text { Adjusted } \\
\mathrm{R} \text { square }\end{array}$ & \multicolumn{2}{|c|}{ StdError of the Estimate } \\
\hline & 0.636 & 0.404 & 0.392 & \multicolumn{2}{|c|}{0.4724} \\
\hline
\end{tabular}

Considering the two items of the independent variable (KFC should have modern equipment and Employees should be well dressed) which established a statistically significant impact on the dependant variable (Service quality of KFC-GHANA, KUMASI), the hypothesis that Service Tangibility of Consumers' Expectations has a positive statistic significant impact on Service quality of KFC-GHANA, KUMASI is accepted on the following grounds;

$$
Y=0.325 X 1+0.537 X 2+0.032
$$

Where; $Y=$ Dependent Variable (Service quality of KFC-GHANA, KUMASI)

$X 1=$ Independent Variable (KFC Should have modern equipment)

$X 2=$ Independent Variable (Employees Should be well dressed) Table 4-11 Coefficients for Regression Model (Tangibility Expectation)/

\begin{tabular}{lccccc}
\hline & B & Std. Error & Std. Beta & t & Sig. \\
\hline (Constant) & 0.032 & 0.143 & & 0.225 & 0.822 \\
KFC should have modern equipment & 0.325 & 0.067 & 0.318 & 4.837 & 0.000 \\
Emplovees should be well dressed & 0.538 & 0.072 & 0.489 & 7.443 & 0.000 \\
\hline
\end{tabular}

Source: Field data from IBM SPSS, 26.

\subsubsection{Impact of Service Tangibility of Consumers' Perceptions on Service Quality of KFC GHANA, KUMASI} (H2)

The second hypothesis (H2), Service Tangibility of Consumers' Perceptions has a positive significant impact on the Service quality of KFC- GHANA, KUMASI is presented in the table below:

Considering the data presented in the table below, two out of the three items identified under the independent variable (Service Tangibility of Consumers' Perceptions) established a statistically significant $(0.000 ; 0.016<$ 0.05) relationship with the dependant variable (Service quality of KFC- GHANA, KUMASI).

A further with the help of stepwise regression analysis revealed an adjusted R square figure of 0.455 . 
Table 4-12 Relationship between Service Tangibility of Consumers' Perceptions and Service Quality of KFC-GHANA, KUMASI

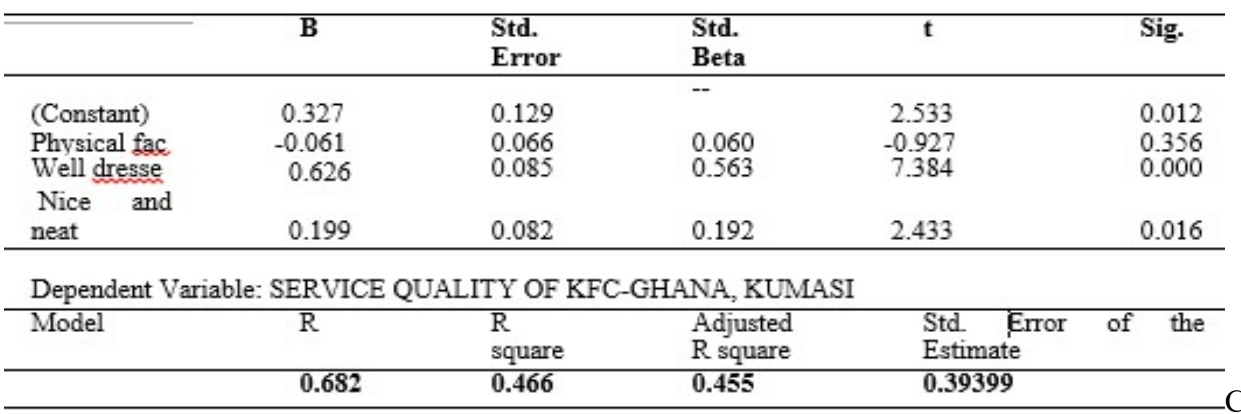

two items of the independent variable (Employees are well dressed and Nice \& Neat environment) which established statistically significant relationship with the dependent variable (Service quality of KFC-GHANA, KUMASI), the hypothesis that Service Tangibility of Consumers' Perceptions has a positive significant impact on Service quality of KFC-GHANA, KUMASI is accepted on the following grounds;

$$
Y=0.623 X 1+0.179 X 2+0.249
$$

Where; $Y=$ Dependent Variable (Service quality of KFC-GHANA, KUMASI)

$X 1=$ Independent Variable (Employees are well dressed) $X 2=$ Independent Variable (Nice \& Neat environment)

Table 4-13 Coefficient for Regression Model (Independent Variables)

\begin{tabular}{lccccc}
\hline & $\mathrm{B}$ & Std. Error & Std. Beta & $\mathrm{t}$ & Sig. \\
\hline (Constant) & 0.249 & 0.098 & & 2.539 & 0.012 \\
Employees are well dressed & 0.623 & 0.085 & 0.561 & 7.357 & 0.000 \\
Nice and Neat Environment & 0.179 & 0.079 & 0.173 & 2.271 & 0.025 \\
\hline
\end{tabular}

Source: Field data from IBM SPSS, 26.

4.3.3 Impact of Service Reliability of Consumers' Expectations on Service Quality of KFC-GHANA, KUMASI (H3)

The third hypothesis (H3), Service Reliability of Consumers' Expectations has a positive significant impact on the Service quality of KFC- GHANA, KUMASI is presented in the table below:

Considering the data presented in the table below, two out of the three items identified under the independent variable (Service Reliability of Consumers' Expectations) established a statistically significant $(0.017 ; 0.000<$ 0.05 ) relationship with the dependant variable (Service quality of KFC- GHANA, KUMASI). A further test with the help of stepwise regression analysis revealed an adjusted R square figure of 0.095 .

Table 4-14 Relationship between Service Reliability of Consumers' Expectations and Service Quality of KFC-GHANA, KUMASI

\begin{tabular}{|c|c|c|c|c|c|}
\hline & B & Std. Error & Std. Beta & $t$ & Sig. \\
\hline (Constant) & 0.885 & 0.139 & & 6.366 & 0.000 \\
\hline $\begin{array}{l}\text { Customer problems should be treated with } \\
\text { sincere }\end{array}$ & 0.241 & 0.100 & 0.264 & 2.418 & 0.017 \\
\hline Perform service right the first time & 0.288 & 0.074 & 0.327 & 3.872 & 0.000 \\
\hline Provide service at promised time & -0.192 & 0.102 & -0.218 & -1.891 & 0.061 \\
\hline \multicolumn{6}{|c|}{ a. Dependent Variable: SERVICE QUALITY OF KFC-GHANA, KUMASI } \\
\hline Model & $\mathrm{R}$ & R Square & $\begin{array}{l}\text { Adjusted } \\
\text { Square }\end{array}$ & \multicolumn{2}{|c|}{$\begin{array}{l}\text { Std. Error of the } \\
\text { Estimate }\end{array}$} \\
\hline$\overline{1}$ & 0.337 & 0.114 & 0.095 & \multicolumn{2}{|c|}{0.4802} \\
\hline
\end{tabular}

Considering the two items of the independent variable (Customers' problems should be treated with sincere interest and KFC should perform the service right the first time) which established statistically significant relationship with the dependant variable (Service quality of KFC-GHANA, KUMASI), the hypothesis that 
Service Reliability of Consumers' Perceptions has a positive significant impact on the Service quality of KFCGHANA, KUMASI is accepted on the following grounds;

$$
Y=0.110 X 1+0.235 X 2+0.872
$$

Where; $Y=$ Dependent Variable (Service quality of KFC-GHANA, KUMASI)

$X 1=$ Independent Variable (Customers' problems should be treated with sincere interest) $X 2=$ Independent Variable (Employees Should be well dressed)

Table 4-15 Coefficient for Regression Model (Independent Variables)

\begin{tabular}{llllll}
\hline & $\mathrm{B}$ & Std. Error & Std. Beta & $\mathrm{t}$ & Sig. \\
\hline (Constant) & 0.872 & 0.140 & & 6.229 & 0.000 \\
Employees are well dressed & 0.110 & 0.072 & 0.120 & 1.520 & 0.131 \\
Nice and Neat Environment & 0.235 & 0.070 & 0.267 & 3.383 & 0.001 \\
\hline
\end{tabular}

Source: Field data from IBM SPSS, 26.

4.3.4 Impact of Service Reliability of Consumers' Perceptions on Service Quality of KFC-GHANA, KUMASI (H4) The fourth hypothesis (H4), Service Reliability of Consumers' Perceptions has a positive significant impact on the Service quality of KFC- GHANA, KUMASI is presented in the table below:

Considering the data presented in the table below, two out of the three items identified under the independent variable (Service Reliability of Consumers' Expectations) established a statistically significant $(0.000 ; 0.000<$ 0.05 ) relationship with the dependant variable (Service quality of KFC- GHANA, KUMASI). A further test with the help of stepwise regression analysis revealed an adjusted R square figure of 0.424 .

Table 4-16 Relationship between Service Reliability of Consumers' Perceptions and Service Quality of KFC-GHANA, KUMASI

\begin{tabular}{lccccc}
\hline & $\mathrm{B}$ & Std. Error & Std. Beta & $\mathrm{t}$ & Sig. \\
\hline $\begin{array}{l}\text { (Constant) } \\
\begin{array}{l}\text { Customers' problems should be sincerely } \\
\text { treated }\end{array}\end{array}$ & 0.201 & 0.115 & & 1.750 & 0.082 \\
$\begin{array}{l}\text { Provider provides service right the first time } \\
\text { Provides the service at the promised time }\end{array}$ & 0.366 & 0.070 & 0.096 & 1.300 & 0.196 \\
$\begin{array}{l}\text { a. Dependent Variable: SERVICE QUALITY OF KFC-GHANA, KUMASI } \\
\text { Model }\end{array}$ & R & Rsquare & $\begin{array}{c}\text { Adjusted } \\
\text { Square }\end{array}$ & $\begin{array}{c}\text { Std. Error of the } \\
\text { Estimate }\end{array}$ \\
\hline 1 & 0.298 & 0.078 & 0.351 & 4.705 & 0.000 \\
\hline
\end{tabular}

Considering the two items of the independent variable (Provider performs service right the first time and Provides the service at the promised time) which established statistically significant relationship with the dependant variable (Service quality of KFC-GHANA, KUMASI), the hypothesis that Service Reliability of Consumers' Perceptions has a positive significant impact on the Service quality of KFC-GHANA, KUMASI is accepted on the following grounds;

$$
Y=0.376 X 1+0.339 X 2+0.281
$$

Where; $Y=$ Dependent Variable (Service quality of KFC-GHANA, KUMASI)

$X 1=$ Independent Variable (Provider performs service right the first time)

$X 2=$ Independent Variable (Provides the service at the promised time)

Table 4-17 Coefficient for Regression Model (Independent Variables)

\begin{tabular}{llllll}
\hline & $\mathrm{B}$ & Std. Error & Std. Beta & $\mathrm{t}$ & Sig. \\
\hline (Constant) & 0.281 & 0.097 & & 2.896 & 0.004 \\
Employees are well dressed & 0.376 & 0.078 & 0.361 & 4.851 & 0.000 \\
Nice and Neat Environment & 0.339 & 0.066 & 0.383 & 5.144 & 0.000 \\
\hline
\end{tabular}

Source: Field data from IBM SPSS, 26. 
4.3.5 Impact of Service Responsiveness of Consumers' Expectations on Service Quality of KFC-GHANA, KUMASI (H5)

The fifth hypothesis (H5), Service Responsiveness of Consumers' Expectations has a positive significant impact on the Service quality of KFC- GHANA, KUMASI is presented in the table below:

Considering the data presented in the table below, two out of the three items identified under the independent variable (Service Responsiveness of Consumers' Expectations) established a statistically significant (0.000;0.014 $<0.05$ ) relationship with the dependant variable (Service quality of KFC- GHANA, KUMASI). A further test with the help of stepwise regression analysis revealed an adjusted R square figure of 0.343 .

\begin{tabular}{|c|c|c|c|c|c|}
\hline - & B & Std. Error & Std. Beta & $\mathbf{t}$ & Sig. \\
\hline (Constant) & 0.265 & 0.125 & & 2.117 & 0.036 \\
\hline $\begin{array}{l}\text { Employees should give prompt service to } \\
\text { customers }\end{array}$ & 0.043 & 0.058 & 0.051 & 0.741 & 0.460 \\
\hline Employees should be willing to help customers & 0.568 & 0.082 & 0.495 & 6.923 & 0.000 \\
\hline Employees should never be too busy to respond & 0.169 & 0.068 & 0.179 & 2.480 & 0.014 \\
\hline \multicolumn{6}{|c|}{ Dependent Variable: SERVICE QUALITY OF KFC-GHANA, KUMASI } \\
\hline \multirow[t]{2}{*}{ Model } & $\mathrm{R}$ & R square & $\begin{array}{l}\text { Adjusted R } \\
\text { square }\end{array}$ & \multicolumn{2}{|c|}{$\begin{array}{l}\text { Std. Error of the } \\
\text { Estimate }\end{array}$} \\
\hline & 0.597 & 0.356 & 0.343 & \multicolumn{2}{|c|}{0.3688} \\
\hline
\end{tabular}

Considering the two items of the independent variable (Employees should be willing to help customers and Employees should never be busy to respond to customers) which established statistically significant relationship with the dependant variable (Service quality of KFC-GHANA, KUMASI), the hypothesis that Service Responsiveness of Consumers' Expectations has a positive significant impact on the Service quality of KFCGHANA, KUMASI is accepted on the following grounds;

$$
Y=0.577 X 1+0.179 X 2+0.309
$$

Where; $Y=$ Dependent Variable (Service quality of KFC-GHANA, KUMASI)

$X I=$ Independent Variable (Employees should be willing to help customers)

$X 2=$ Independent Variable (Employees should never be busy to respond to customers)

Table 4-19 Coefficient for Regression Model (Independent Variables)

\begin{tabular}{llllll}
\hline & $\mathrm{B}$ & Std. Error & Std. Beta & $\mathrm{t}$ & Sig. \\
\hline (Constant) & 0.309 & 0.110 & & 2.800 & 0.006 \\
$\begin{array}{l}\text { Employees should be willing to help } \\
\text { customers }\end{array}$ & 0.577 & 0.081 & 0.503 & 7.122 & 0.000 \\
$\begin{array}{l}\text { Employees should never be too busy } \\
\text { Source: Field data from IBM SPSS, 26. }\end{array}$ & 0.179 & 0.067 & 0.189 & 2.685 & 0.008 \\
\hline
\end{tabular}

4.3.6 Impact of Service Responsiveness of Consumers' Perceptions on Service Quality of KFC-GHANA, KUMASI (H6)

The sixth hypothesis (H6), Service Responsiveness of Consumers' Perceptions has a positive significant impact on the Service quality of KFC- GHANA, KUMASI is presented in the table below:

Considering the data presented in the table below, two out of the three items identified under the independent variable (Service Responsiveness of Consumers' Perceptions) established a statistically significant $(0.000 ; 0.000$ $<0.05$ ) relationship with the dependant variable (Service quality of KFC- GHANA, KUMASI). A further test with the help of stepwise regression analysis revealed an adjusted R square figure of 0.370 . 
Table 4-20 Relationship between Service Responsiveness of Consumers' Perceptions and Service Quality of KFC-GHANA, KUMASI

\begin{tabular}{|c|c|c|c|c|c|}
\hline- & $\mathbf{B}$ & Std. Error & Std. Beta & $\mathbf{t}$ & Sig. \\
\hline (Constant) & 0.262 & 0.097 & & 2.711 & 0.008 \\
\hline Employees give prompt service to customers & 0.204 & 0.050 & 0.300 & 4.117 & 0.000 \\
\hline Always willing to help customers & 0.333 & 0.050 & 0.465 & 6.636 & 0.000 \\
\hline Employees are never too busy to respond & 0.075 & 0.048 & 0.121 & 1.575 & 0.117 \\
\hline \multicolumn{6}{|c|}{ Dependent Variable: SERVICE QUALITY OF KFC-GHANA, KUMASI } \\
\hline \multirow[t]{2}{*}{ Model } & $\mathrm{R}$ & R square & $\begin{array}{l}\text { Adjusted R } \\
\text { square }\end{array}$ & \multicolumn{2}{|c|}{$\begin{array}{l}\text { Std. Error of the } \\
\text { Estimate }\end{array}$} \\
\hline & 0.619 & 0.383 & 0.370 & \multicolumn{2}{|l|}{0.3038} \\
\hline
\end{tabular}

Considering the two items of the independent variable (Employees give prompt service to customers and Always willing to help customers) which established statistically significant relationship with the dependant variable (Service quality of KFC-GHANA, KUMASI), the hypothesis that Service Responsiveness of Consumers' Perceptions has a positive significant impact on the Service quality of KFC-GHANA, KUMASI is accepted on the following grounds;

$$
Y=0.239 X 1+0.362 X 2+0.268
$$

Where; $Y=$ Dependent Variable (Service quality of KFC-GHANA, KUMASI)

$X 1=$ Independent Variable (Employees give prompt service to customers) $X 2=$ Independent Variable (Always willing to help customers)

Table 4-21 Coefficient for Regression Model (Independent Variables)

\begin{tabular}{llllll}
\hline & B & Std. Error & Std. Beta & t & Sig. \\
\hline (Constant) & 0.268 & 0.097 & & 2.763 & 0.006 \\
$\begin{array}{l}\text { Employees give prompt service to } \\
\text { customers }\end{array}$ & 0.239 & 0.045 & 0.351 & 5.370 & 0.000 \\
$\begin{array}{l}\text { Always willing to help customers } \\
\text { Slo }\end{array}$ & 0.362 & 0.047 & 0.506 & 7.748 & 0.000 \\
\hline
\end{tabular}

Source: Field data from IBM SPSS, 26.

4.3.7 Impact of Service Assurance of Consumers' Expectations on Service Quality of KFC-GHANA, KUMASI (H7)

The seventh hypothesis (H7), Service Assurance of Consumers' Expectations has a positive significant impact on the Service quality of KFC- GHANA, KUMASI is presented in the table below:

Considering the data presented in the table below, one out of the three items identified under the independent variable (Service Assurance of Consumers' Expectations) established a statistically significant $(0.000<0.05)$ relationship with the dependant variable (Service quality of KFC- GHANA, KUMASI). A further test with the help of stepwise regression analysis revealed an adjusted R square figure of 0.445 . 


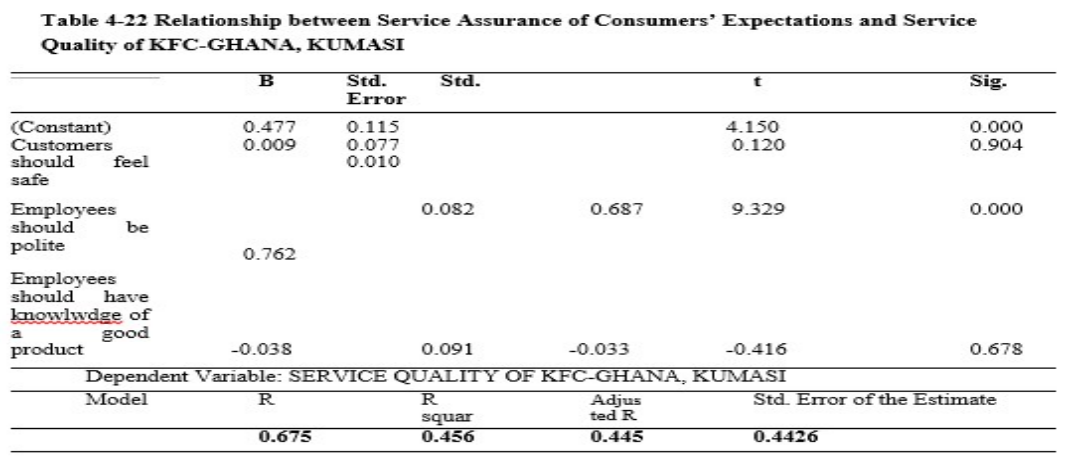

Considering the independent variable (Employee should be polite) which established statistically significant relationship with the dependant variable (Service quality of KFC-GHANA, KUMASI), the hypothesis that Service Assurance of Consumers' Expectations has a positive significant impact on the Service quality of KFCGHANA, KUMASI is accepted on the following grounds;

$$
Y=0.748 X+0.457
$$

Where; $Y=$ Dependent Variable (Service quality of KFC-GHANA, KUMASI) $X 1=$ Independent Variable (Employee should be polite)

Table 4-23 Coefficient for Regression Model (Independent Variables)

\begin{tabular}{lccccl}
\hline & $\mathrm{B}$ & Std. Error & Std. Beta & $\mathrm{t}$ & Sig. \\
\hline (Constant) & 0.457 & 0.094 & & 4.872 & 0.000 \\
Employees should be polite & 0.748 & 0.067 & 0.675 & 11.116 & 0.000
\end{tabular}

Source: Field data from IBM SPSS, 26.

4.3.8 Impact of Service Assurance of Consumers' Perceptions on Service Quality of KFC-GHANA, KUAMSI (H8) The eighth hypothesis (H8), Service Assurance of Consumers' Perceptions has a positive significant impact on the Service quality of KFC- GHANA, KUMASI is presented in the table below: Considering the data presented in the table below, one out of the three items identified under the independent variable (Service Assurance of Consumers' Perceptions) established a statistically significant $(0.000 ; 0.000<0.05)$ relationship with the dependant variable (Service quality of KFC- GHANA, KUMASI). A further test with the help of stepwise regression analysis revealed an adjusted $\mathrm{R}$ square figure of 0.507

\begin{tabular}{|c|c|c|c|c|}
\hline $\mathrm{B}$ & Std. Error & Std. Beta & $\mathrm{t}$ & Sig. \\
\hline (Constant) & 0.096 & & 0.384 & 0.702 \\
\hline \multirow{2}{*}{$\begin{array}{l}\text { Customer feel safe in } 0.404 \\
\text { their transactions } \\
\text { Employees are polite } 0.450\end{array}$} & 0.112 & 0.478 & 3.602 & 0.000 \\
\hline & 0.061 & 0.439 & 7.353 & 0.000 \\
\hline $\begin{array}{l}\text { Employees } \quad \text { have }_{0.004} \\
\text { knowledge }\end{array}$ & 0.117 & 0.005 & 0.035 & 0.972 \\
\hline \multicolumn{5}{|c|}{ a. Dependent Variable: SERVICE QUALITY OF KFC-GHANA, KUMASI } \\
\hline Model & R Square & Adjusted R Square & \multicolumn{2}{|c|}{ Std. Error of the Estimate } \\
\hline 0.718 & 0.517 & 0.507 & \multicolumn{2}{|l|}{0.3459} \\
\hline
\end{tabular}

Considering the two items of the independent variable (Customers feel safe in their transactions with employees and Employees are polite with customers) which established statistically significant relationship with the dependant variable (Service quality of KFC-GHANA, KUMASI), the hypothesis that Service Assurance of Consumers' Perceptions has a positive significant impact on the Service quality of KFC-GHANA, KUMASI is accepted on the following grounds;

$$
Y=0.407 X 1+0.450 X 2+0.037
$$

Where; $Y=$ Dependent Variable (Service quality of KFC-GHANA, KUMASI)

$X I=$ Independent Variable (Customers feel safe in their transactions with employees)

$X 2=$ Independent Variable (Employees are polite with customers) 
Table 4-25 Coefficient for Regression Model (Independent Variables)

\begin{tabular}{llllll}
\hline & B & Std. Error & Std. Beta & t & Sig. \\
\hline (Constant) & 0.037 & 0.096 & & 0.388 & 0.698 \\
Customer feel safe in their transactions & 0.407 & 0.050 & 0.482 & 8.202 & 0.000 \\
Employees should be polite & 0.450 & 0.060 & 0.439 & 7.476 & 0.000 \\
\hline
\end{tabular}

Source: Field data from IBM SPSS, 26.

4.3.9 Impact of Service Empathy of Consumers' Expectations on Service Quality of KFC-GHANA, KUMASI (H9) The ninth hypothesis (H9), Service Empathy of Consumers' Expectations has a positive significant impact on the Service quality of KFC- GHANA, KUMASI is presented in the table below:

Considering the data presented in the table below, two out of the three items identified under the independent variable (Service Empathy of Consumers' Expectations) established a statistically significant $(0.000 ; 0.000<$ 0.05) relationship with the dependant variable (Service quality of KFC- GHANA, KUMASI). A further test with the help of stepwise regression analysis revealed an adjusted $\mathrm{R}$ square figure of 0.331 .

Table 4-26 Relationship between Service Empathy of Consumers' Expectations on Service Quality of KFC-GHANA, KUMASI

\begin{tabular}{|c|c|c|c|c|c|}
\hline & B & Std. Error & Std. Beta & $t$ & Sig. \\
\hline (Constant) & 0.101 & 0.128 & & 0.787 & 0.432 \\
\hline Operating hours should be convenient to all & 0.375 & 0.082 & 0.433 & 4.602 & 0.000 \\
\hline Personal service should be readily available to all & 0.388 & 0.055 & 0.490 & 7.030 & 0.000 \\
\hline Employees must understand specific needs of & -0.046 & 0.069 & -0.064 & -0.675 & 0.501 \\
\hline \multicolumn{6}{|c|}{ a. Dependent Variable: SERVICE QUALITY OF KFC-GHANA, KUMLASI } \\
\hline Model & $\mathrm{R}$ & Rsquare & $\begin{array}{l}\text { Adjusted } \\
\text { Square }\end{array}$ & \multicolumn{2}{|c|}{$\begin{array}{l}\text { Std. Error of the } \\
\text { Estimate }\end{array}$} \\
\hline$\overline{1}$ & 0.587 & 0.344 & 0.331 & \multicolumn{2}{|l|}{0.3598} \\
\hline
\end{tabular}

Considering the two items of the independent variable (Operating hours should be convenient to all customers and Personal Service should be readily available to all) which established statistically significant relationship with the dependant variable (Service quality of KFC-GHANA, KUMASI), the hypothesis that Service Empathy of Consumers' Expectations has a positive significant impact on the Service quality of KFC-GHANA, KUMASI is accepted on the following grounds;

$$
Y=0.337 X 1+0.379 X 2+0.102
$$

Where; $Y=$ Dependent Variable (Service quality of KFC-GHANA, KUMASI)

$X 1=$ Independent Variable (Operating hours should be convenient to all customers)

$X 2=$ Independent Variable (Personal Service should be readily available to all)

Table 4-27 Coefficient for Regression Model (Independent Variables)

\begin{tabular}{lccccc}
\hline & B & Std. Error & Std. Beta & t & Sig. \\
\hline (Constant) & 0.102 & 0.128 & & 0.800 & 0.425 \\
Operating hours should be convenient & 0.337 & 0.058 & 0.389 & 5.780 & 0.000 \\
Personal service should be readily & 0.379 & 0.053 & 0.478 & 7.114 & 0.000 \\
\hline
\end{tabular}

Source: Field Data from IBM SPSS, 26.

4.3.10 Impact of Service Empathy of Consumers' Perceptions on Service Quality of KFC-GHANA, KUMASI (H10)

The tenth hypothesis (H10), Service Empathy of Consumers' Perceptions has a positive significant impact on the Service quality of KFC- GHANA, KUMASI is presented in the table below: Considering the data presented in the table below, two out of the three items identified under the independent variable (Service Empathy of Consumers' Perceptions) established a statistically significant $(0.000 ; 0.000<0.05)$ relationship with the dependant variable (Service quality of KFC- GHANA, KUMASI). A further test with the help of stepwise regression analysis revealed an adjusted R square figure of 0.728 . 


\begin{tabular}{|c|c|c|c|c|c|}
\hline & B & $\begin{array}{l}\text { Std. } \\
\text { Error }\end{array}$ & Std. Beta & $\mathbf{T}$ & Sig. \\
\hline (Constant) & 0.051 & 0.067 & -- & 0.759 & 0.449 \\
\hline Operating & 0.018 & 0.035 & & 0.502 & 0.616 \\
\hline hours & & & 0.024 & & \\
\hline Employees & 0390 & 0.047 & 0.477 & 8.338 & 0.000 \\
\hline $\begin{array}{l}\text { Employees } \\
\text { understand }\end{array}$ & 0.517 & 0.066 & 0.453 & 7.842 & 0.000 \\
\hline \multicolumn{6}{|c|}{ Dependent Variable: SERVICE QUALITY OF KFC-GHANA, KUMASI } \\
\hline Model & $\mathrm{R}$ & $\begin{array}{l}\mathrm{R} \\
\text { square }\end{array}$ & $\begin{array}{l}\text { Adjusted } \\
\mathrm{R} \text { square }\end{array}$ & $\begin{array}{l}\text { Std Error } \\
\text { Estimate }\end{array}$ & of the \\
\hline & 0.856 & 0.733 & 0.728 & 0.2398 & \\
\hline
\end{tabular}

Considering the two items of the independent variable (Employees give customers personal service and Employees understand specific needs of customers) which established statistically significant relationship with the dependant variable (Service quality of KFC-GHANA, KUMASI), the hypothesis that Service Empathy of Consumers' Perceptions has a positive significant impact on Service quality of KFC-GHANA, KUMASI is accepted on the following grounds;

$$
\begin{gathered}
Y=0.394 X 1+0.525 X 2+0.066 \\
\text { Where; Y= Dependent Variable (Service quality of KFC-GHANA, KUMASI) } \\
X 1=\text { Independent Variable (Employees give customers personal service) } \\
X 2=\text { Independent Variable (Employees understand specific needs of customers) }
\end{gathered}
$$

\begin{tabular}{|c|c|c|c|c|c|}
\hline & B & Std. Error & Std. Beta & $\Gamma$ & Sig. \\
\hline (Constant) & 0.066 & 0.060 & & 1.088 & 0.278 \\
\hline Operating hours should be convenient & 0.394 & 0.046 & 0.483 & 3.622 & 0.000 \\
\hline Personal service should be readily & 0.525 & 0.064 & 0.460 & 3.224 & 0.000 \\
\hline
\end{tabular}

Table 4-29 Coefficient for Regression Model (Independent Variables)

4.4 Service Quality for KFC-GHANA, Kumasi Services.

Here, the researcher assessed service quality for some services at KFC-GHANA, Kumasi. These services include; Online services, delivery time, cost of delivery, voucher availability and prices of products. Consumers were to register their satisfaction or dissatisfaction by selecting the options of Very Satisfied, Satisfied, and Not Satisfied. From the table below, the results show that averagely, consumers are more satisfied with the Delivery Time of KFC-GHANA, Kumasi. This is represented from the table with a mean value of 2.18. Moreover, from the same table, the results show that Delivery Time scored the less standard deviation of 0.53 . This could be interpreted that consumers' satisfaction for the Delivery Time does not deviate or fluctuate from their normal behavior (Mean).

Table 4-30 Descriptive Statistics for Consumers Satisfaction of KFC-GHANA, Kumasi Services

\begin{tabular}{lccccc}
\hline Services & N & \multicolumn{1}{c}{ Minimum } & Maximum & Mean & Std. Deviation \\
\hline Online Service & 150 & 1.0 & 3.0 & 1.76 & 0.62 \\
Delivery Time & 150 & 1.0 & 3.0 & 2.18 & 0.53 \\
Cost of Delivery & 150 & 1.0 & 3.0 & 1.67 & 0.82 \\
Voucher Availability & 150 & 1.0 & 3.0 & 1.62 & 0.81 \\
Price of Products & 150 & 1.0 & 3.0 & 1.61 & 0.80 \\
Valid N (Listwise) & 150 & & & & \\
\hline
\end{tabular}

\subsection{Multi-Factor Regression Analysis}

The simple ordinary least squares (OLS) technique was used to conduct this analysis. Diagnostics tests for multicollinearity and model fitness were performed using the variance inflator factor (VIF), F-test and Rsquare statistics. Results as reported in the table below indicate that, the problem of collinearity was minimized. Results of the VIF statistics were all below 10. The conditional indices were also small below 30; further indicating that multicollinearity was not present in the model. Standardized results of the OLS regression are presented in the table below. The F-test and R-square statistics also showed that the model was robust for analysis. From the table below, we realize that Service Responsiveness had the most impact on the Service Quality of KFC-Ghana, Kumasi with a t-5.201, next is Service Tangibility with 4.804, after that is Service Assurance with 4.792, 
followed by Service Reliability with 4.661 and the dimension which made the least impact is Service Empathy with 3.075 .

Table 4-31 Multi Factor Analysis

\begin{tabular}{llllll}
\hline & Beta & $\mathrm{t}$ & Sign. & Tolerance & VIF \\
\hline Service Tangibility & .204 & 4.804 & .000 & .875 & 1.106 \\
Service Reliability & .101 & 4.661 & .000 & .753 & 1.023 \\
Service Empathy & .120 & 3.075 & .000 & .632 & 1.520 \\
Service Assurance & .133 & 4.792 & .000 & .789 & 1.303 \\
Service Responsiveness & .310 & 5.201 & .000 & .820 & 1.201 \\
\hline
\end{tabular}

\subsection{Summary}

This section discusses in brief the results of the findings and analysis and the following findings or results were derived from the study; Age is one item under the background of the respondents. The results show that, out of the one hundred and fifty (150) respondents, forty-three (43) respondents representing $28.7 \%$ were under the ages of 40-44. This shows that majority of the respondents who patronize the services of KFC-GHANA, KUMASI were adults. This also helps the study because adults are experienced. Also, about gender under the background of respondents, the outcome shows that out of the one hundred and fifty respondents, ninety (90) respondents which represents $60 \%$ were females. This means that majority of the respondents who use the services of KFC-GHANA, KUMASI are females. When it comes to location to proximity, it is shown in the results that, out of the one hundred and fifty respondents, eighty-six (86) of the respondents which represented $57.3 \%$ were living within or close to the same location as KFC-GHANA, KUMASI. This means that majority of people who patronize KFC-GHANA, KUMASI stay closer to the restaurant. The last part of the background of the respondents is about how often people visit or use KFC-GHANA, KUMASI. According to the result, 74 respondents which represents $49.3 \%$ use or patronize KFC-GHANA, KUMASI on a monthly basis. This can be further explained that most of the respondents use the services of KFC-GHANA, KUMASI monthly. The result from the first hypothesis test in Table 4-10 shows that Service Tangibility of Consumers Expectations has statistically significant relationship on the Service quality of KFC-GHANA, KUMASI. Most specifically, among the independent variables identified under Service Tangibility of Consumers' Expectations, 'KFC should have modern equipment' and 'Employees should be well dressed' had the most significant impact (i.e., 0.000, 0.000) on the dependent variable, Service quality of KFC-GHANA, KUMASI. The result from Table 4-12 of the hypothesis test shows that Service Tangibility of Consumers' Perceptions has a statistically significant relationship on the Service quality of KFC-GHANA, KUMASI. Most specifically, among the independent variables identified under Service Tangibility of Consumers' Perceptions, 'Employees are well dressed' had the most significant impact (i.e,0.00) on the dependent variable, 'Service quality of KFC-GHANA, KUMASI.

Statistically, from Table 4-14 of the hypothesis test, the outcome reviewed that, Service Reliability of Consumers' Expectations has a significant relationship on the Service quality of KFC-Ghana, Kumasi. Among all the independent variables identified under Service Reliability of Consumers' Expectations, the specific one that had the most significant impact on the dependent variable, 'Service quality of KFC-Ghana, Kumasi was 'Employees perform the service right the first time' (i.e., 0.000).

From Table 4-16, it is shown in the hypothesis test that Service Reliability of Consumers' Perceptions has a statistically significant relationship on the Service quality of KFC-Ghana, Kumasi. Specifically, among the independent variables identified under Service Reliability of Consumers' Perceptions, 'Provider provides service right the first time' and 'Provider provides the service at the promised time' (i.e., 0.000, 0.000) had the most significant impact on the dependent variable, 'Service quality of KFC-Ghana, Kumasi'.

From Table 4-18, the outcome of the first hypothesis test review that 'Service Responsiveness of Consumers Expectations' has a statistically significant relationship on the Service quality of KFC-Ghana, Kumasi. Among the independent variables identified under Service Responsiveness of Consumers' Expectations, 'Employees should be willing to help customers' (i.e., 0.000) had the most significant impact on the dependent variable, Service quality of KFC-Ghana, Kumasi.

Also from Table 4-20, the outcome of the first hypothesis test review that 'Service Responsiveness of Consumers Perceptions' has a statistically significant relationship on the Service quality of KFC-Ghana, Kumasi. Among the independent variables identified under Service Responsiveness of Consumers' Perceptions, 'Employees give prompt service to customers' and 'Employees are Always willing to help customers' (i.e., $0.000,0.000$ ) had the most significant impact on the dependent variable, Service quality of KFC-Ghana, Kumasi. 
From Table 4-22, it is shown in the hypothesis test that Service Assurance of Consumers' Expectations has a statistically significant relationship on the Service quality of KFC-Ghana, Kumasi. Specifically, among the independent variables identified under Service Assurance of Consumers' Expectations, 'Employees should be polite' (i.e., 0.000) had the most significant impact on the dependent variable, 'Service quality of KFC-Ghana, Kumasi'.

From Table 4-24, it is shown in the hypothesis test that Service Assurance of Consumers' Perceptions has a statistically significant relationship on the Service quality of KFC-Ghana, Kumasi. Specifically, among the independent variables identified under Service Assurance of Consumers' Perceptions, 'Employees feel safe in their transactions' and 'Employees are polite with customers' (i.e., 0.000, 0.000) had the most significant impact on the dependent variable, 'Service quality of KFC-Ghana, Kumasi'.

The result from Table 4-26 of the hypothesis test shows that Service Empathy of Consumers' Expectations has a statistically significant relationship on the Service quality of KFC-GHANA, KUMASI. Most specifically, among the independent variables identified under Service Empathy of Consumers' Expectations, 'Operating hours should be convenient to all' and Employees must understand specific needs of customers' had the most significant impact (i.e, $0.000,0.000$ ) on the dependent variable, Service quality of KFC-Ghana, Kumasi.

Lastly from the hypothesis test of the independent and dependent variables, it is seen that the result from Table 4-28 that Service Empathy of Consumers' Perceptions has a statistically significant relationship on the Service quality of KFC-Ghana, Kumasi. Most specifically, among the independent variables identified under Service Empathy of Consumers' Perceptions, 'Employees give personal service' and Employees understand specific needs of customers' had the most significant impact (i.e, $0.000,0.000)$ on the dependent variable, Service quality of KFC-Ghana, Kumasi.

From Table 4-30, the results show that on the average, consumers are more satisfied with the Delivery Time of KFC-Ghana, Kumasi. The table presents that Delivery Time had a mean value of 2.18 which also has less standard deviation of 0.53 . This means that consumers' satisfaction for the Delivery Time does not deviate from their normal behavior (Mean).

Lastly, from Table 4-31, the results show that Service Responsiveness had the most impact on the Service Quality of KFC-Ghana, Kumasi with a t-5.201, next is Service Tangibility with 4.804, after that is Service Assurance with 4.792 , followed by Service Reliability with 4.661 and the dimension which made the least impact is Service Empathy with 3.075.

Furthermore, from the analysis of the hypothesis testing, it was realized that all the independent variables which are the five (5) dimensions of the SERVQUAL model under Consumers' Expectations (i.e., Service Tangibility, Service Reliability, Service Responsiveness, Service Assurance and Service Empathy) had statistically significant relationship on the dependent variable, Service quality of KFC-Ghana, Kumasi.

It was also realized from the analysis of the hypothesis testing that all the independent variables which are the five (5) dimensions of the SERVQUAL model under Consumers' Perceptions (i.e., Service Tangibility, Service Reliability, Service Responsiveness, Service Assurance and Service Empathy) had statistically significant relationship on the dependent variable, Service quality of KFC-Ghana, Kumasi.

Therefore, it can be said that, all the hypothesis of the study, was redetected after the analysis. Even though all the independent variables had a significant relationship statistically with the dependent variable Service quality of KFC-Ghana, Kumasi, five (5) of them had the most significant relationship than others. The independent variables that had the most significant relationship with the dependent variable Service quality of KFC-Ghana, Kumasi are; Service Empathy of Consumers' Expectations, Service Empathy of Consumers' Perceptions, Service Responsiveness of Consumers' Perceptions, Service Reliability of Consumers' Perceptions and Service Assurance of Consumers' Perceptions.

\subsubsection{Conclusions and Recommendations}

\subsubsection{Conclusions}

This part of the study outlines the final thoughts of the researcher about the whole study. Some goals and objectives were set for this study so here, it will be made known whether they were achieved or not.

Mentioned in previous chapters, one of the objectives was to measure the service quality of KFC-Ghana using the SERVQUAL model. It was to know, whether or not the dimensions under the SERVQUAL model had an impact on the service quality of KFC-Ghana, Kumasi. After thorough research, findings and analysis, it can be 
concluded that the SERVQUAL model which was introduced by Parasuraman et al in 1985 for the measurement of service quality, actually has an impact on the service quality of KFC-Ghana, Kumasi. Thus, the researcher's objective was achieved.

Also, another objective was to know which the best dimension is perceived by the customers of KFC-Ghana, Kumasi. According to the results, all the dimensions under SERVQUAL model are best to the perception of customers because they all had an impact on the service quality of KFC-Ghana, Kumasi.

\subsubsection{Recommendations to management of KFC-Ghana, Kumasi}

KFC-Ghana, Kumasi should put more focus on products and services that fits the majority

According to the findings of this study, it was realized that majority of the respondents who visit or use the services and products of KFC-Ghana, Kumasi were from the ages of Forty to Forty-Four (40-44), the rest of the age groups were just a fair number of respondents. In view of this, it is suggested by the researcher that the management of KFC-Ghana, Kumasi should put more effort in the products and services that draw the majority to their premise.

Expansion of branches: It was shown in the analysis that eighty-six (86) out of the one hundred and fifty (150) respondents were living close to the premise of KFC-Ghana, Kumasi. This means that majority of the respondents who stay at the same location as KFC-Ghana, Kumasi have a high tendency to visit or patronize them. In view of this, it has been suggested that, management of KFC-Ghana, Kumasi should make it a need to open up other branches at different locations. This will enable people to have easy access to their products and services. Employees' motivation: According to the results, most of the independent variables had a significant relationship with the dependent, Service quality of KFC-Ghana, Kumasi. This can be further explained based on the various questions the respondents answered that, the customers or consumers most of the times were satisfied by the employees' reactions or treatments. The attitude of the staff or employees towards customers in one way or the other has an impact on the service quality of KFC-Ghana, Kumasi. In view of this, it is further suggested by the researcher that, the management can put in place some incentive packages for the staff or employees which will make maintain the quality services they are providing to customers.

Lastly on recommendations, KFC-Ghana, Kumasi should pay much attention to their Delivery Time. It was observed in the analysis that, most of the respondents or customers of KFC-Ghana, Kumasi were satisfied with their Delivery Time. Therefore, it is recommendable to put much effort in maintaining their Delivery Time in other for them not to fall back. what customers appreciate, must be made more attractive to satisfy or entice them the more.

\section{REFERENCES}

1 Sekaran, U., Bougie, R. (2009). Research Methods for Business: A Skill Building Approach. A John Wiley and Sons, Ltd, Publication

2 Anderson, E.W., Fornell, C., \& Lehmann, D.R. (1994), customer satisfaction, market share and profitability: findings from Sweden, Journal of Marketing, 58(3), 53-66

3 Awwad, M. S. (2012). An application of the American Customer Satisfaction Index (ACSI) in the Jordanian mobile phone sector. The TQM Journal, 24(6), 529-541. http://dx.doi.org/10.1108/17542731211270098

4 Al Khattab, S. A., \& Aldehayyat, J. S. (2011). Perceptions of Service Quality in Jordanian Hotels. International Journal of Business and Management, 6(7), 226-233. http://dx.doi.org/10.5539/ijbm.v6n7p226

5 Bennett. R and Barkensio A. (2005) Relationship quality, relationship marketing, and client perceptions of the levels of service quality of charitable organizations, International Journal of Service Industry Management , 16(1) 81-106

6 Boulding, William, Ajay Kalra, Richard Staelin, and Valarie A. Zeithaml (1993), A Dynamic Process Model of Service Quality: From Expectations to Behavioural Intentions, Joumal of Marketing Research, 30, , 7-27

7 Bowen and David E. (2005) Service Quality Blackwell encyclopedic Dictionary of Human Resource management, Pl 341, 340P

8 Bojanic, D. C., \& Rosen, L.D (1994), "Measuring Service Quality in Restaurants: An Application of the SERVQUAL Instrument", Hospitality Research Journal,18(1), 4-14

9 Brown, T.J., Churchill, G.A. and Peter, J.P. (1993) research note: Improving the measurement of service quality, Journal of retailing, 69(1) 126-139

10 Brown, S.W. and Bond, E.U. III (1995), "The internal/external framework and service quality: Toward theory in services marketing", Journal of Marketing Management, February, pp. 25-39 
11 Brogowicz, A. A., Delene, L. M., \& Lyth, D. M. (1990). A synthesised service quality model with managerial implications. International Journal of Service Industry Management, 1(1), 27-44. http://dx.doi.org/10.1108/ 09564239010001640

12 Cronin, J. J., \& Taylor, S. A. (1992). Measuring service quality: A reexamination and extension. Journal of Marketing, 56(3), 55-68. http://dx.doi.org/10.2307/1252296

13 Dabholkar, P. A., Shepherd, C. D., \& Thorpe, D. I. (2000). A comprehensive framework for service quality: An investigation of critical conceptual and measurement issues through a longitudinal study. Journal of Retailing, 76(2), 131-139. http://dx.doi.org/10.1016/S0022-4359(00)00029-4

14 Fu, Y.Y (1999), "Service Quality Dimensions Influencing Older Diners' Intention to Return", Proceedings of Fourth Annual GraduateEducation and Graduate Students Research Conference in Hospitality and Tourism, 549-558.

15 Fornell, C. (1992). "A National Customer Satisfaction Barometer: The Swedish Experience." Journal of Marketing, Vol. 56, p.6-21.

16 Fornell, C., Johnson, M.D., Anderson, E.W., Cha, J. and Bryant, B.E. (1996), The American customer satisfaction index: nature, purpose and findings, Journal of Business Research, 60(4), 7-18

17 Giese, J. L., \& Cote, J. A. (2002). Defining Consumer Satisfaction, Academy of Marketing Science, Vol. 2000, Number 1, p.1-24.

18 Gronroos, C. (1984). A service quality model and its marketing implications. European Journal of Marketing, 18(4), 3644. http://dx.doi.org/10.1108/EUM0000000004784

19 Heung, V. C. S. (2000). Satisfaction levels of mainland Chinese travelers with Hong Kong hotel services. International Journal of Contemporary Hospitality Management, 12(5), 308-315. http://dx.doi.org/10.1108/ 09596110010339689

20 Jain, S. K., \& Gupta, G. (2004). Measuring Service Quality: SERVQUAL vs. SERVPERF Scales. Vikalpa, 29(2), 2535

21 Kotler P., Armstrong G., Saunders J. Wong V. (2002) Principle of Marketing, 3rd edition, Pretence Hall \$Europe.

22 Kotler, P. and Keller, K. L. (2009) Marketing management (13th end). New Jersey: Pearson Education Inc, Upper Saddle River,

23 Kumar, M., Kee, F. T. \& Manshor, A. T. (2009). Determining the relative importance of 73 critical factors in delivering service quality of banks; An application of dominance analysis in SERVQUAL model, Managing Service Quality, 19(2), 211- 228.

24 Kuo. YF (2003) A study on service quality of virtual community websites, Total Quality Management \& Business Excellence, 13 (4), 461-473

25 Laroche. M, Kalamas. M., Cheikhrouhou. S., Cezard A., (2004) Canadian Journal Of Administrative Sciences-Revue Canadienne Des Sciences De L Administration , 21(4), 361-375

26 Lee, H., Lee, Y. \& Yoo, D. (2000). The determinants of perceived service quality and its relationship with satisfaction, Journal of Service Marketing, 14(3), 217-231.

27 Parasuraman, A., Zeithaml, V. A., \& Berry, L. L. (1985). A conceptual model of service quality and its implications for future research, Journal of Marketing, 49, 41-50.

28 Parasuraman, A., Zeithaml, V.A. and Berry, L.L (1988), "SERVQUAL: a multi-item scale formeasuring consumerperceptions of the service quality",

29 Journal of Retailing, Vol. 64, No. 1, 12-40.

30 Parasuraman A., Zeithaml V. A. and Berry Leonard L (1988), "SERVQUAL: AMultiple-Item Scale for Measuring Consumer Perceptions of Service Quality", Journal of Retailing, 64 (1), (Spring), 12-37.

31 Micheal.R Solomon (2009). Consumer behaviour, Buying, Having and Being, 8th edition, Pearson education, inc.

32 Saravanan, R. \& Rao, K. S. P. (2007). Measurement of service quality from the customer's perspective - An empirical study, Total Quality Management, 18(4) p.435-449.

33 Sivadas, Eugene; Baker-Prewitt, Jamie L (2000) An examination of the relationship between service quality, customer satisfaction, and store loyalty, Journal of Retail \& Distribution Management, 28(2)73-82

34 Sureshchandar G.S., Rajendran C, \& Anantharaman R.N. (2002) the relationship between service quality and customer satisfaction - a factor specific approach, Journal of Services Marketing, 16(4), 363 - 379.

35 Schiffman, L. G. and LazarKanuk, L. (2004) Consumer Behaviour. 8th edition. New Jersey Pearson Education Inc, Upper Saddle River Titus

36 Sureshchandar G.S., Rajendran C, \& Anantharaman R.N. (2002) the relationship between service quality and customer satisfaction - a factor specific approach, Journal of Services Marketing, 16(4), 363 - 379.

37 Spreng, R.A., Mackenzie, S.B. and Olshavsky, R.W. (1996) A re-examination of the determinant of customer satisfaction, journal of Marketing, 60(3), 15-32

38 Tse, David K. \& Peter, C. Wilton. (1988). Models of Consumer Satisfaction: An Extension, Journal of Marketing Research, 25 204-212. 
39 Türkyilmaz, A., \& Özkan, C. (2007). Development of a customer satisfaction index model: An application to the Turkish mobile phone sector. Industrial Management \& Data Systems, 107(5), 672-687. http://dx.doi.org/10. $\underline{1108 / 02635570710750426}$

40 Wilson A., Zeithaml V.A., Bitner M.J., Gremler D.D. (2008) Services Marketing, McGraw-Hill Education

41 Yi, Y. (1990). A critical review of consumer satisfaction, in Zeithaml, V.(Eds), Review of Marketing, American Marketing Association, Chicago, IL, p.68-123.

42 Zeithaml V. A., Bitner M. J., Gremler D. D. (2006) Services marketing, 4th edition, McGraw-Hill

43 David C Bojanic, L Drew Rosen (1994). Measuring service quality in restaurants: an application of the SERVQUAL instrument. Hospitality Research Journal 18 (1), 3-4.

44 SUZANA Markovic, JELENA Komsic, MIHAELA Stifanic (2013). Measuring service quality in city restaurant settings using DINESERV scale.Recent Advances in Business Management and Marketing 181, 176-181.

45 Shu-Yun Yin, Kuan-Kai Huang, Jiunn-I Shieh, Yu-Huei Liu, Hsin-Hung Wu (2016). Telehealth services evaluation: a combination of SERVQUAL and importance-service quality analysis.Quality \& Quantity 50 (2), 751-766.

46 Yun Lok Lee, Nerilee Hing (1995). Measuring quality in restaurant operations: an application of the SERVQUAL instrument. International Journal of Hospitality management 14(3-4), 293-310.

47 Lokesh Vijayvargy (2014). Measuring Service Quality Using SERVQUAL: A Case of Restaurant Chain. International Journal of Management \& Innovation 6 (2).

48 MI Mohammed, YL Gambo, MM Omirin (2012). Assessing facilities management service in postgraduate hostel using servqual technique. Journal of Emerging Trends in Economics and Management Sciences 3 (5), 485-490.

49 Muhammed S Alnsour, Bandar Abu Tayeh, Mohammed Awwad Alzyadat (2014). Using SERVQUAL to assess the service quality if service provided by Jordan telecommunications Sector. International Journal of Commerce and Management.

50 Farouk Saleh, Chris Ryan (1991). Analysing service quality in the hospitality industry using the SERVQUAL model. Service Industries Journal 11 (3), 324-345.

51 Simon SK Lam, Ka Shing Woo (1997). Measuring service quality: a test-retest reliability investigation of SERVQUAL. International Journal of Market Research 39 (2), 381.

52 Dushica Saneva, Sonja Chortoseva (2018). Service quality in restaurants: Customers' expectation and customers' perception. 